\title{
Transmission of Bank Liquidity Shocks in Loan and Deposit Markets: The Role of Interbank Borrowing and Market Monitoring
}

\author{
Franklin Allen \\ The Wharton School of the University of Pennsylvania \\ Aneta Hryckiewicz \\ University of Frankfurt and Kozminski University \\ Oskar Kowalewski \\ Warsaw School of Economics (SGH) \\ Günseli Tümer-Alkan* \\ VU University Amsterdam
}

November, 2010

\begin{abstract}
We examine the international transmission of bank liquidity shocks from multinational bankholding companies to their subsidiaries. Our findings are consistent with the studies that document that parent bank fragility negatively affects lending by subsidiaries. We further find that reduction in foreign bank lending is stronger for those that are dependent on the interbank market. Moreover, foreign bank lending is determined by different factors in emerging markets and in developed countries. Finally, we show that liquidity needs determine the change in deposits in developing economies, especially during the recent crisis whereas market discipline is relatively more dominant in developed countries.
\end{abstract}

Keywords: foreign banks, credit supply, market discipline

JEL Codes: F15, F34, G21

*Corresponding author: Günseli Tümer-Alkan, VU University Amsterdam, Department of Finance, De Boelelaan 1105, 1081 HV Amsterdam, The Netherlands, tel: 3120598 7430, fax: 3120598 6020, email: gtumeralkan@feweb.vu.nl 


\section{Introduction}

International transmission of financial shocks is the subject of several studies in the banking literature. One of the channels identified is the transmission of liquidity shocks from parent banks' balance sheets to their subsidiaries' lending activity. Previous studies find that foreign bank subsidiaries rely heavily on the use of internal capital that may result in propagation of domestic liquidity shocks and reduced lending (Peek and Rosengren, 1997, 2000). Recent research that focuses on the influence of the global liquidity crisis on the lending of foreign subsidiaries confirms the previous results and shows that foreign banks reduced their lending during the subprime crisis (Popov and Udell, 2010).

Little is known, however, how this mechanism works, what is the role of the interbank market and which banks and countries are particularly affected. We try to answer these questions by examining the foreign bank subsidiary channel and by including the recent global crisis. Moreover, we expand the existing work by investigating at the same time the existence of market discipline in host countries in relation to parent banks' financial conditions. We contribute to the recent literature on international transmission of financial distress as we also focus on credit and deposit activity of foreign bank subsidiaries during a global crisis, whereas the results provide valuable suggestions for the future regulation of multinational banking.

In the last two decades financial integration resulted in an increase of foreign ownership in the banking sectors across large number of countries. A long line of research supports this development by documenting the stabilizing role of foreign banks in developing countries (Demirgüç-Kunt and Enrica, 1997). Foreign bank entry is associated with credit growth and reduced likelihood of crises. ${ }^{1}$ Moreover, empirical studies show that foreign bank lending

\footnotetext{
${ }^{1}$ See Clarke et al. (2003) for a review.
} 
remained unaffected during local crises, partly due to the support from parent banks (Martinez Peria et al., 2002 and de Haas and van Lelyveld, 2006, 2010).

While adverse affects of local crises are mitigated by foreign banks, home country economic cycles may influence the host country as documented by Peek and Rosengren (1997, 2000). However, there is limited and mixed evidence on whether or not international banking may have adverse effects on financial stability. Jeanneau and Micu (2002) find a positive relationship between bank lending to emerging countries and the economic cycles in the developed countries. Goldberg (2001) documents a negative effect for Asia and positive effect for Latin America, while Martinez Peria et al. (2002) find that home country problems increase foreign lending in developing countries. Also de Haas and van Lelyveld (2010) find that home country business cycles negatively affect the credit growth of subsidiaries, whereas the strength of a parent bank has a positive influence. Popov and Udell (2010) investigate the effect of financial distress of parent banks on loan rejection rates in regions where the subsidiary is located. The paper documents the existence of loan supply shocks to Central and Eastern European (CEE) countries during the recent crisis and reports that foreign banks reduced lending to a greater extent compared to domestic banks during the crisis. However, it does not identify a direct influence of the parent bank on its subsidiaries.

As a result we do not know whether all or only selected foreign banks reduced lending during the crisis. Nevertheless, in this paper we try to shed some light on this by analyzing the determinants of foreign subsidiaries' lending behaviour across different countries by examining outside the crisis period as well. As we assume that one of the possible channels for the observed reversal in lending is the funding of the foreign banks, we extend further the analysis by focusing on market discipline and investigating whether subsidiary and parent bank characteristics can explain the behaviour of deposits and deposit rates. Namely, we 
expect that depositors in the host country may have penalized subsidiaries of riskier parent banks by withdrawing their savings, which may explain the shortage of funding and a reduction in their lending during the crisis.

Indeed, using a sample of 51 multinational banks and their subsidiaries in 99 countries, we find evidence that parent bank fragility (such as higher loan loss provisions) reduces lending by subsidiaries. The results show that during the crisis, one of the main determinants of lending has been the ability to borrow in the interbank market. We document that reduction in foreign bank lending in the host countries is more significant for those foreign banks that were strongly dependent on the interbank market. Moreover, we also find that the decline in foreign bank lending is partially determined by different factors in emerging markets and in developed countries. We attribute it to the different structure of the foreign banks in the emerging markets, which consist of banks acquired as a process or privatization as well as de novo banks. In contrast, multinational banks target poor performing banks in developed countries, a potential reason for the inefficiency of foreign banks in those markets (Peek et al, 1999). In our opinion, the differences in the structure of the banks in developed and developing countries drive the mixed results for market discipline, suggesting that it plays a more important role in developed countries. Again, one of the determinants of banks' liquidity needs seems to be the access to the interbank market by the foreign banks.

Our paper is related to a number of studies on the impact of the recent crisis on foreign banks in the host countries (Popov and Udell, 2010; Navaretti et al., 2010). It builds upon existing empirical work on intra banking that makes use of subsidiary and parent bank-level variation to identify the determinants of foreign lending (de Haas and van Lelyveld, 2010). Overall, our main results confirm the existence of a subsidiary channel, yet we emphasize also the importance of the interbank market in this transmission mechanism. We also document 
that the sensitivity of lending by foreign banks to parent bank characteristics differ in developed and emerging markets. Finally, we provide new evidence on the effects of market discipline on foreign subsidiaries during a global financial crisis. To the best of our knowledge, this study is the first to investigate the market discipline in an international transmission context.

These findings have numerous policy implications concerning the recent increasing trend in foreign ownership in the banking sectors. The current crisis and the recent evidence on reduced lending by foreign banks in CEE emerging markets may question the idea of liberalizing and opening the banking sectors to foreign capital. The problem does not only concern emerging markets but also developed countries such as United Kingdom or the Scandinavian countries and their experience with Icelandic foreign banks.

While we do not explore the variation in ownership, we document that foreign banks that rely on interbank markets reduce their lending significantly during a crisis that originates in the home country. Hence, access to capital seems to be important in understanding foreign bank activity. This also suggests that multinational banks should be regulated as one unit by an international supervisory authority, or more power should be extended to that authority, as suggested by Pistor (2010).

The remainder of the paper is organized as follows. In section 2, we describe the data, our empirical strategy and our hypotheses. We investigate the impact of parents' financial performance on the loan supply and deposit collection of their subsidiaries and present the estimation results in section 4 . Section 5 concludes.

\section{Data and Methodology}

The sample used in this study consists of multinational banks and their foreign subsidiaries. We select the multinational banks using a 2008 ranking published by the Banker 
magazine, where we concentrate only on the first 150 banks. We exclude those banks that do not have any foreign subsidiary, or when we are not able to retrieve data for them. Using this methodology we select the 51 largest banks from twenty developed countries and all of their subsidiaries in the world ${ }^{2}$. We exclude, however, those subsidiaries that were located in the same country as the parent bank since we are mainly interested in identifying the international transmission of financial shocks. Table A1 and A2 in the Appendix present the list of parent banks, number of subsidiaries for each bank and the list of countries with foreign subsidiaries in the sample.

We obtain financial data for multinational banks and their subsidiaries from the BankScope database. We use unconsolidated financial data for the multinational banks and consolidated statements for their subsidiaries. We convert all bank variables into US dollars. Our data cover the period from 1990 to 2008, but the panel is unbalanced due to missing information on some institutions and years.

We examine the international transmission of bank liquidity shocks from multinational bank holding companies to their subsidiaries. To test our hypothesis we follow the approach established in de Haas and van Lelyveld (2010). However, our analysis distinguishes itself from this paper by including a broader sample in terms of the time period, number of multinational banks and countries covered. Moreover, we expand the investigation by including the role of interbank market dependency as well as studying the parent effects on market discipline in different countries, taking into account the period of global crisis.

\subsection{Variable Definitions}

In the first part of the paper we aim to examine the link between a parent bank and the credit supply of its foreign affiliate. De Haas and van Leyveld (2010) show that lending

\footnotetext{
${ }^{2}$ The subsidiaries are located in 113 countries including both developed and developing economies. We also exclude offshore financial centres. The final sample of subsidiaries consists of 99 countries.
} 
growth of a foreign subsidiary is not only determined by its own but also by its parent's health and by host and home country variables. We follow their approach in constructing our empirical strategy. We use the annual change in loans (LLoans), representing the first difference of the log of total loans for a subsidiary, as the dependent variable. When explaining the change in loans, we also explore the differences between developed and emerging countries.

We include subsidiary and parent bank characteristics as well as host and home country variables. Bank variables for both groups include loan loss provisions to net interest revenues (Loan Loss), return on equity (ROE), equity to total assets (Equity) and liquid assets to total assets (Liquidity). ${ }^{3}$ We include Size defined as $\log$ of total assets only as a subsidiary characteristic. Finally, we include Interbank ratio defined as interbank lending to borrowing. ${ }^{4}$ We expect that subsidiaries less dependent on interbank market and hence more on deposits may be less affected by the problems of the parent banks as they substitute for internal markets.

The second group consists of location specific factors and includes country level controls. We include the GDP Growth (host and home country) and Exchange Rate in US Dollars. We expect that foreign banks will expand lending if local GDP and the currency are strong. In addition, we include the Concentration Ratio, defined as the share of assets of three largest banks to the assets of all commercial banks in a host country. We expect that highly concentrated banking sectors will be less affected by the liquidity shock transmission due to the power of existing banks. We also include Cost to Income to control for the efficiency of the banking sector, measured as total costs as a share of total income of all commercial banks

\footnotetext{
${ }^{3}$ Alternatively, we also include ROA to measure profitability and the results remain virtually unchanged.

${ }^{4}$ In the estimations, we do not include Liquidity and Interbank ratio simultaneously as Liquidity is potentially determined by interbank lending and borrowing. We choose not to report the results with Interbank ratio that are inline with the reported results.
} 
in the host country. We expect that more efficient banks are able to better react to market conditions and thus will not be as strongly affected by the liquidity shock transmission as the other banks. Table 1 provides a list of variable definitions and Table 2 presents the summary statistics.

One word of caution is needed when the loan supply shock is examined, as it is crucial to identify supply and demand effects. Country specific variables enable us to isolate loan demand effects to some extent. Moreover, we can potentially identify the external liquidity shock by including the interbank transactions of home and host countries. However, transmission of shocks may occur through two interdependent channels: parent bank's lending to foreign subsidiaries and through cross-border lending, which would affect the entire economy including domestic banks as well (Cetorelli and Goldberg, 2009). Although we cannot trace the transactions between the foreign subsidiaries and the parent banks, we can identify such an external shock to subsidiaries by investigating the ratio of aggregate interbank lending/borrowing of a foreign bank and its parent bank to distinguish 'the credit channels to subsidiaries' from 'cross-border lending'.

\subsection{Market discipline}

In the second part of the paper, we focus on market discipline and test whether bank and parent bank characteristics can explain the behavior of deposits and deposit rates. We also investigate whether these effects differ between the developing and developed countries.

Most empirical findings document the existence of market discipline. ${ }^{5}$ Martinez Peria and Schmukler (2001) investigate the role of deposit insurance in market discipline during the crisis. They find that deposit insurance does not diminish the degree of market discipline. In a later study, Martinez Peria et al. (2004) examine the relationship between the systemic risk

\footnotetext{
${ }^{5}$ See Flannery (1998), De Ceuster and Masschelein (2003), Kaufman (2003), and Flannery and Nikolova, (2004).
} 
and market discipline and identify their mechanisms. The authors find that systemic shocks increase the degree of market discipline regardless of banks' fundamentals. Following these studies, we introduce the following variables to test for market discipline. First, we use deposit growth defined as the first difference of the log of time deposits, $\Delta$ Time Deposits. We expect a positive relationship between banks' fundamentals and time deposits as existing studies reported that depositors punish banking institutions for excessive risk taking by withdrawing their savings. We also include the change in bank deposits ( $\triangle$ Bank Deposits) as the second market discipline measure. The effect is expected to be higher for bank deposits compared to time deposits, as bank deposits are not covered under deposit insurance schemes. Since depositors can also discipline banks by requiring higher interest rates, we introduce a third dependent variable, Interest Rates. We use an implicit measure, as in Martinez Peria and Schmukler (2001), by dividing the total interest rate expenses by total interest bearing deposits. Consequently, we also control for subsidiary and parent bank characteristics, included into regressions as lagged variables.

\section{Results}

\subsection{Lending Channel}

We explore the impact of home country shocks on foreign subsidiaries' lending by estimating:

$$
\Delta \text { Loan }_{i t}=f\left(\text { Bank }_{i t}, \text { Country }_{i t}, \text { ParentBank }_{i t}, \text { ParentCountry }_{i t}\right)
$$

where $\Delta$ Loan $_{i t}$ is the change in total loans of subsidiary $i$ in year $t ;$ Bank $_{i t}$ is a matrix of foreign subsidiary controls of subsidiary $i$ and Country $_{i t}$ is a matrix of macroeconomic variables of the country where the subsidiary $i$ is located. ParentBank $k_{i t}$ is a matrix of parent 
bank characteristics of subsidiary $i$ in year $t$; ParentCountry $y_{i t}$ is a matrix of macroeconomic variables of the parent bank country of subsidiary $i$.

Table 3 reports the fixed effects panel estimation results explaining the change in loans of a subsidiary. In the first three specifications, we present the results for the entire panel. ${ }^{6}$ The first specification includes subsidiary and host country characteristics. In the second specification, we add the parent bank and home country variables. The number of observations drops significantly due to lack of certain variables and the unbalanced structure of the data. In the third specification, we introduce a new variable, Crisis, equal to one for the years 2007 and 2008 that should capture the impact of the recent financial crisis. We also interact this variable with each parent bank characteristics to investigate whether we find a different or stronger impact of the lending channel during the crisis in the home countries. We further exclude the Asian parents in these estimations as the crisis originated in the U.S. and the European banks were also hit relatively earlier by the financial crisis than the rest of the world.

The results show that foreign subsidiaries with higher capitalization reduce lending, while other internal factors are insignificant. On the other hand, higher economic growth in the host country and a stronger currency has a positive influence on a foreign bank's lending. We also find evidence for the lending channel, as an increase in loan loss provisions of the parent negatively affects the loan growth of a subsidiary. Moreover, we also show that lower GDP in the home country increases the lending activity of foreign subsidiaries. Hence, the results suggest a substitution effect, which is in line with the previous findings of de Haas and van

\footnotetext{
${ }^{6}$ In all estimations, we exclude the host countries that are considered as offshore financial centers. We exclude the following countries: Bahamas, Bermuda, Cayman Islands, Cyprus, Gibraltar, Liechtenstein, Luxembourg, Malta, Monaco, Netherlands Antilles, Seychelles, Switzerland, Vanuatu and Western Samoa. However, re-estimating our model including those countries does not change our results.
} 
Lelyveld (2010). We do not find, however, evidence for the impact of parent characteristics on subsidiary lending during the crisis of 2007-2008.

The data present large variation between foreign subsidiaries operating in developed and developing countries (see Table 2). We therefore split the sample and estimate the same model separately for those two groups of countries. We distinguish them using the World Bank classification form 2008. The results, shown in Table 3, confirm that lending by foreign subsidiaries in developing and developed countries are not determined by the same set of factors. Specifically, "lending-channel" is more relevant for the developing economies. On the other hand, in more advanced economies bank internal factors determine the lending activity. Loan loss provisions of the parent bank seem to affect both groups, however the results are stronger for the developing countries. Nevertheless, other bank characteristics do not have an influence for the sample of these countries. Conversely, we find a negative and statistically significant coefficient of size and equity ratio among the subsidiary characteristics located in developed countries. The results could signal that it is easier for multinational banks to operate on a smaller scale in developed countries, where the competition is very high and sophisticated. The fierce competition in those countries reflects the lower profitability of subsidiaries in developed countries in comparison to those operating in developing countries. Moreover, Classens and van Horen (2009) document that foreign banks tend to perform better compared to domestic banks when coming from a high-income country, which may explain the low profitability of subsidiaries in developed countries.

Among the macroeconomic variables, economic growth and exchange rate matter only for developing countries. Furthermore, we also observe a significant impact of market structure on the lending growth in the developing countries. The coefficient of market concentration is positive and statistically significant, yet at ten percent level. On the other hand, we observe 
that a substitution effect dominates in developed countries. In other words, home country problems increase foreign lending in developed countries. Moreover, subsidiaries of highly capitalized and liquid banks decrease their lending during the recent crisis if they are located in a developed country.

Lastly, to explore the mechanisms of the financial shock transmission, we split the developing country sample based on Interbank ratio of the subsidiary. The first (second) group includes banks with an interbank ratio below (above) one and is considered as more (less) dependent on interbank borrowing. In other words, it means that the first group of subsidiaries finances its lending abroad using the interbank market, which is a risky strategy and turned fatal for many banks during the recent crisis. In contrast, an interbank ratio above one means that the foreign subsidiary is a net placer on the interbank market and hence it should not have been constrained in lending by the liquidity crunch during the recent crisis. Moreover, we hypothesize that the shock is transmitted through the interbank channel to subsidiaries. However, as direct transactions between the foreign subsidiaries and the parent banks are not available, we aim to capture this by including the interbank ratio of the parent bank in the last specification. The results of the estimations are presented in Table 4. In general, we find that subsidiaries with higher reliance on interbank market are more sensitive to the parent's financial performance. The results suggest that subsidiaries that rely more heavily on interbank borrowing decrease their lending when the parent banks have higher loan loss provisions. The magnitude of the effect becomes even stronger during the crisis and when we control for the interbank ratio of the parent. We also find that subsidiaries reduce their lending during the crisis when the parent bank is profitable. An explanation for the results is the substitution effect observed by de Haas and van Leyveld (2010), where the funds are diverted from foreign subsidiaries to the parent bank, when it is more profitable. Another and not mutually exclusive explanation is that the reduced lending is the result of the liquidity 
crunch observed during the crisis, which increased the cost and reduced significantly the availability of funding for foreign subsidiaries through the interbank markets. As a result of the substitution effect, those foreign banks that relied heavily on interbank markets and had at the same time profitable parent banks could not substitute the shortcoming and needed to scale down during the crisis. Indeed, we find that foreign subsidiaries with a higher interbank ratio increase their lending when the parent has higher loan loss provisions during the crisis. This behavior confirms the substitution effect that we did not find for developing countries in previous estimations. However, the coefficient is only significant at the ten percent level.

\subsection{Market Discipline}

We estimate the following model to examine the existence of the market discipline in relation to the transmission of financial shocks:

MarketDiscipline $_{i t}=f\left(\right.$ Bank $_{i t-1}$, Country $_{i t}$, ParentBank $_{i t-1}$, ParentCountry $\left._{i t}\right)$

We include a similar set of variables to explain the market discipline variables. We measure market discipline by $\Delta$ Time Deposits, $\Delta$ Bank Deposits and Interest Rates respectively. Table 5 presents the results for the entire sample. We report the results using both fixed and random effects estimators. We use random effects estimator in order to include the deposit insurance dummy that is not time varying. However, we report the random effects estimators only when the Hausman test is not rejected.

In general, most specifications indicate the existence of market discipline and certain subsidiary and parent fundamentals influence the change in time deposits. We find that the depositors react to a deterioration of bank performance and punish their institutions by withdrawing their savings. In the first group of results, we find some evidence for an inverse effect of loan loss provisions on time deposit growth. We also find that subsidiaries with more 
profitable parents can increase their time deposits during the recent crisis, a result not supported by the random effects estimator.

In the second panel, we do not report the random effects results, first because controlling for deposit insurance is not needed when explaining bank deposits, and second because the results are in line with the fixed effects models. We find that profitable and capitalized subsidiaries experience a decrease in interbank borrowing, pointing to a lower need and preference for liquidity. Alternatively, this might indicate the support provided from a parent institution to a financially weak foreign affiliate through the interbank deposits. This finding is also consistent with the previous evidence, where we report that parent banks tend to support their subsidiaries during local economic contraction. Moreover, an increase in loan loss provisions of the parent leads to a decrease in bank deposits during the recent crisis, which can be attributed to two possible reasons. First, a worsening in the performance of the parent may have induced the participants in the interbank market to decrease their lending to the subsidiary. Second, if the parent is a significant lender to the subsidiary, having problems in the loan portfolio may lead them to reduce lending to their subsidiaries. Similarly, if the parent bank decides to stay more liquid during the crisis in the home country, their subsidiaries experience reduction in bank deposit accounts.

The results on interest rates continue to support the existence of market monitoring. Stronger and larger subsidiaries are not required to pay higher deposit rates. The estimations show that higher loan loss provisions increase the deposit rates of a foreign affiliate. Higher loan loss provisions by the parent are also related to higher interest rates paid, pointing to the difficulties subsidiaries face in collecting deposits.

Table 6 and Table 7 present the same model specifications for developing and developed countries, respectively. Our findings suggest that in developing countries the market 
discipline is determined by both factors: subsidiary fundamentals and its parent bank. On the other hand, subsidiaries in developed countries do not seem to be affected much by parent bank fundamentals. We find that loan loss provisions of the parent bank negatively (positively) influence the time deposits (interest rates) in developing countries. In developed countries, most subsidiary variables play a role. We also observe a difference between the countries during the crisis. Although the results differ to a certain extent within the groups, they suggest that market discipline is of less importance during the crisis. We find that subsidiaries with profitable parents experience an increase in their time deposits. However, loan loss provisions by the parent (when interacted with the crisis dummy), lead to an increase in time deposits of the subsidiary. We further document that bank deposits in developing countries are inversely affected by increases in parents' liquidity ratios as in the previous estimations. Our findings suggest that foreign banks in developing countries experienced a liquidity shock due to their parent's financial condition where they were forced to fight for other funds. A special report by Fitch Ratings (2009) explains such a change in funding strategy at parent banks where they delegate more responsibility to their subsidiaries in terms of deposit collection in emerging countries. As a consequence, the parent banks were ring-fencing their foreign subsidiaries by reducing the funding available to them. In many countries, the reduced funding to foreign subsidiaries may have destabilized the whole system and hence the necessary liquidity was provided by programs introduced ad hoc by national central banks or multinational organizations such as EBRD or IMF in Central Europe (Pistor, 2010). Indeed, the situation confirmed the possibility of a "nightmare situation" described by Herring (2007), whereas the foreign subsidiaries with large shares in the host markets become systematically important, while at the same time they are not that important for the parent bank because of their small size relative to the multinational banking group. 
In line with the previous section, we split the sample of subsidiaries in developing countries based on the Interbank ratio, again. As before, the first (second) group includes banks with an interbank ratio below (above) one. Table 8 presents the results for both groups explaining the change in time deposits and interest rates. We find that highly capitalized subsidiaries in the first group have lower time deposits. We also document that during the crisis, funding concerns play a more important role for the sample of banks relying on interbank borrowing. While higher loan loss provisions of the parent lead to a decrease in time deposits, the total effect turns to be positive in the crisis, suggesting again a change in the funding strategy as found in the previous estimations. However, for the sub-sample of foreign banks with an interbank ratio higher than one, the results point to the existence of market discipline. Stronger banks with higher equity and with capitalized parents experience an increase in time deposit levels during the crisis. In addition, higher loan loss provisions of the parent lead to higher deposit rates. On the other hand, subsidiaries of profitable parents are also able to afford to pay higher rates.

\section{Conclusion}

In this paper, we investigate the international transmission of bank liquidity shocks from multinational bank holding companies to their foreign subsidiaries. Recent studies document that foreign banks reduced their lending during the subprime crisis. However, little is known about the transmission mechanisms. We explore the subsidiary channel by focusing on the role of the interbank market and the differences between countries by examining outside the global crisis period as well. Moreover, we investigate the existence of market discipline in host countries in this context and contribute to the literature on international transmission of financial shocks in deposit markets. 
Our findings are in line with the studies on multinational banks' internal capital markets (de Haas and van Lelyveld, 2010). Using a sample of 51 multinational banks and their subsidiaries, we find evidence that parent bank fragility negatively affects lending by subsidiaries. This effect is stronger for those foreign banks that rely on interbank borrowing. We also find that lending by subsidiaries in developing and developed countries are not determined by the same set of factors. In particular, "lending-channel" seem to be more relevant for the developing economies, whereas in more advanced economies, bank fundamentals determine the lending activity.

Finally, we examine the existence of the market discipline in relation to the transmission of financial shocks. We find that the depositors react to a deterioration of bank performance and punish their institutions by withdrawing money or by asking for higher interest rates. We show that market discipline plays a more important role in developed countries whereas liquidity needs determine the change in deposits in developing economies, especially for banks that rely on interbank borrowing. Moreover, market discipline is weaker during the crisis.

Our findings have several policy implications concerning the recent increasing trend in foreign ownership in the banking sectors in emerging economies and the interbank market transactions. We document that foreign banks that relied on interbank markets reduced their lending significantly during a crisis in the home country. Moreover, the results suggest that the reduction may have been caused by the financial situation of the parent bank as well as changes in its funding strategy towards the subsidiaries. In our opinion, these findings point to the need of regulating and monitoring multinational banks by an international supervisory authority. 


\section{References}

Banking Systems in Emerging Europe, 2009, Europe Special Report, Fitch Ratings.

Cetorelli, N. and L.S. Goldberg, 2009, Globalized Banks: Lending to Emerging Markets in the Crisis, FRB of New York Staff Report No. 377

Clarke, G. R.G., R. Cull, M. S. Martinez Peria and S. M. Sanchez, 2003, Foreign Bank Entry: Experience, Implications for Developing Countries, and Agenda for Further Research, World Bank Research Observer 18 (1), 25-59.

Claessens, S., N. van Horen, 2009. Being a foreigner among domestic banks: asset or liability?, IMF Working Paper WP/09/273, International Monetary Fund,

Cull, R. and M. S. Martinez Peria, 2007, Foreign Bank Participation and Crises in Developing Countries, Policy Research Working Paper Series 4128, The World Bank.

De Ceuster M.J.K. and N. Masschelein, 2003, Regulating banks through market discipline: a survey of the issues, Journal of Economic Surveys 17, pp. 749-766.

De Haas, R. and I. van Lelyveld, 2010, Internal Capital Markets and Lending by Multinational Bank Subsidiaries," Journal of Financial Intermediation, vol. 19(1), 1-25.

De Haas, R. and I. van Lelyveld, 2006, Foreign Banks and Credit Stability in Central and Eastern Europe. A Panel Data Analysis, Journal of Banking and Finance 30, 1927-1952.

Demirguc-Kunt, A. and E. Detragiache, 1997, The Determinants of Banking Crises: Evidence from Industrial and Developing Countries, Policy Research Working Paper Series 1828, The World Bank.

Flannery, M.J., 1998, Using market information in prudential bank supervision: a review of the U.S. empirical evidence, Journal of Money, Credit and Banking 30, 273-305.

Flannery M. J. and S. Nikolova, 2004, Market discipline of U.S. financial firms: recent evidence and research issues. In: W.C. Hunter, G.G. Kaufman, C. Borio and K. Tsatsaronis, Editors, Market Discipline across Countries and Industries, Cambridge University Press.

Goldberg, L.S., 2001, When is US Bank Lending to Emerging Markets Volatile? NBER Working Paper No. 8209, New York.

Herring, R.J., 2007, Conflicts between Home \& Host Country Prudential Supervisors, Wharton Financial Institution Center Working Paper 07-33. 
Jeanneau, S. and M. Micu, 2002, Determinants of International Bank Lending to Emerging Market Countries, BIS Working Paper No. 112, Bank for International Settlements, Basel.

Kaufman G. G., Editor, 2003, Market Discipline in Banking: Theory and Evidence, Research in Financial Services: Private and Public Policy Volume 15, Elsevier.

Martinez Peria, M.S., A. Powell, and I. Vladkova Hollar, 2002, Banking on Foreigners: The Behavior of International Bank Lending to Latin America, 1985-2000, World Bank Working Paper No. 2893. World Bank, Washington, DC.

Martinez Peria, M.S. and S. L. Schmukler, 2001, Do Depositors Punish Banks for Bad Behavior? Market Discipline, Deposit Insurance and Banking Crises, Journal of Finance 56 (3), 1029-1051.

Levy Yeyati, E., M.S. Martinez Peria, and S. L. Schmukler, 2004, Market Discipline under Systemic Risk: Evidence from Bank Runs in Emerging Economies: Beyond Bank Fundamentals, World Bank Policy Research Working Paper No 3440.

Navaretti, B. G, G. Calzolari, A. Pozzolo, and M. Levi, 2010, Multinational Banking in Europe: Financial Stability and Regulatory Implications Lessons from the Financial Crisis, Centro Studi Luca d'Agliano Working Paper No 292.

Peek, J. and E. S. Rosengren, 1997, The International Transmission of Financial Shocks: The Case of Japan, American Economic Review 87 (4), 495-505.

Peek, J. and E. S. Rosengren, 2000, Collateral Damage: Effects of the Japanese Bank Crisis on Real Activity in the United States, American Economic Review 90 (1), 30-45.

Peek, J., E. S. Rosengren and F. Kasirye, 1999, The poor performance of foreign bank subsidiaries: Were the problems acquired or created?, Journal of Banking and Finance vol. 23(2-4), 579-604.

Pistor, K., 2010, Host's Dilemma: Rethinking EU Banking Regulation in Light of the Global Crisis, ECGI - Finance Working Paper No. 286/2010.

Popov, A. and G. F. Udell, 2010, Cross-border Banking and the International Transmission of Financial Distress During the Crisis of 2007-2008, Working Paper Series 1203, European Central Bank 
Table 1 Variable Definitions

\begin{tabular}{|c|c|c|}
\hline Data Source & Variable & Definition \& Measurement \\
\hline \multirow[t]{5}{*}{ BankScope } & Dependent Variables & \\
\hline & $\Delta$ Loans & $\log (\text { Total Loans })_{t}-\log (\text { Total Loans })_{t-1}$ \\
\hline & $\Delta$ Time Deposits & Log $(\text { Time Deposits })_{t}-$ Log (Time Deposits $)_{t-1}$ \\
\hline & $\Delta$ Bank Deposits & $\log (\text { Bank Deposits })_{t}-\log (\text { Bank Deposits })_{t-1}$ \\
\hline & Interest Rates & Interest Rate Expenses to Interest-Bearing Deposit \\
\hline \multirow[t]{8}{*}{ BankScope } & Bank Characteristics & \\
\hline & Total Assets & in million USD \\
\hline & Loan Loss & Loan Loss Provisions to Net Interest Revenues \\
\hline & Equity & Equity to Total Assets \\
\hline & ROE & Return on Equity \\
\hline & Liquidity & Liquid Assets to Total Assets \\
\hline & Interbank & Interbank Lending to Interbank Borrowing \\
\hline & Country Variables & \\
\hline WDI & GDP growth & Yearly change \\
\hline BankScope & Exchange rate & Exchange Rate from Local currency to USD \\
\hline Fitch BankScope & Concentration & $\begin{array}{l}\text { Assets of three largest banks as a share of assets } \\
\text { of all commercial banks } \\
\qquad C R 3_{j t}=\sum_{i=1}^{3} s_{i j t}\end{array}$ \\
\hline \multirow[t]{2}{*}{ Fitch BankScope } & Cost to Income & $\begin{array}{l}\text { Total Costs as a share of Total Income of all } \\
\text { commercial banks }\end{array}$ \\
\hline & Developed & $\begin{array}{r}\text { developed }=1 \\
\text { developing }=0\end{array}$ \\
\hline $\begin{array}{l}\text { Demirguc-Kunt, } \\
\text { Karacaovali and } \\
\text { Laeven (2005) }\end{array}$ & Deposit insurance & $\begin{array}{l}\text { explicit }=1 \\
\text { implicit }=0\end{array}$ \\
\hline
\end{tabular}


Table 2 Summary Statistics

\begin{tabular}{|c|c|c|c|c|}
\hline Variable & & Obs & Mean & Std. Dev. \\
\hline Dependent Variables & Subsidiary & & & \\
\hline \multirow[t]{3}{*}{$\Delta$ Loans } & & 3,254 & 0.088 & 1.061 \\
\hline & Developing & 1,793 & 0.117 & 1.106 \\
\hline & Developed & 1,461 & 0.053 & 1.002 \\
\hline \multirow{3}{*}{$\Delta$ Time Deposits } & & 2,441 & 0.050 & 1.155 \\
\hline & Developing & 1,352 & 0.070 & 1.204 \\
\hline & Developed & 1,089 & 0.026 & 1.091 \\
\hline \multirow[t]{3}{*}{$\Delta$ Bank Deposits } & & 2,767 & 0.069 & 1.513 \\
\hline & Developing & 1,466 & 0.097 & 1.696 \\
\hline & Developed & 1,301 & 0.036 & 1.277 \\
\hline \multirow[t]{3}{*}{ Interest Rates } & & 3,763 & 0.100 & 0.217 \\
\hline & Developing & 2,082 & 0.123 & 0.267 \\
\hline & Developed & 1,681 & 0.072 & 0.127 \\
\hline \multicolumn{5}{|l|}{ Bank Characteristics } \\
\hline \multirow[t]{3}{*}{ Total Assets (mln USD) } & Subsidiary & 4,079 & 9,302 & 38,587 \\
\hline & Developing & 2,280 & 2,269 & 5,627 \\
\hline & Developed & 1,799 & 18,215 & 56,522 \\
\hline \multirow[t]{4}{*}{ Loan Loss } & Subsidiary & 3,591 & 0.175 & 0.651 \\
\hline & Developing & 2,048 & 0.206 & 0.692 \\
\hline & Developed & 1,543 & 0.135 & 0.589 \\
\hline & Parent & 475 & 0.211 & 0.353 \\
\hline \multirow[t]{4}{*}{ Equity } & Subsidiary & 4,072 & 0.124 & 0.127 \\
\hline & Developing & 2,277 & 0.140 & 0.127 \\
\hline & Developed & 1,795 & 0.105 & 0.124 \\
\hline & Parent & 615 & 0.165 & 0.266 \\
\hline \multirow[t]{4}{*}{ ROE } & Subsidiary & 4,057 & 0.131 & 0.375 \\
\hline & Developing & 2,264 & 0.162 & 0.471 \\
\hline & Developed & 1,793 & 0.091 & 0.188 \\
\hline & Parent & 590 & 0.103 & 0.191 \\
\hline \multirow[t]{4}{*}{ Liquidity } & Subsidiary & 2,947 & 0.194 & 0.320 \\
\hline & Developing & 1,536 & 0.193 & 0.222 \\
\hline & Developed & 1,411 & 0.196 & 0.401 \\
\hline & Parent & 451 & 0.132 & 0.150 \\
\hline \multirow[t]{4}{*}{ Interbank } & Subsidiary & 3,023 & 1.708 & 2.104 \\
\hline & Developing & 1,612 & 1.906 & 2.251 \\
\hline & Developed & 1,411 & 1.481 & 1.899 \\
\hline & Parent & 483 & 1.031 & 1.068 \\
\hline \multicolumn{5}{|l|}{ Country Variables } \\
\hline \multirow[t]{4}{*}{ GDP growth } & Subsidiary & 1,410 & 0.043 & 0.045 \\
\hline & Developing & 899 & 0.049 & 0.052 \\
\hline & Developed & 511 & 0.033 & 0.024 \\
\hline & Parent & 273 & 0.026 & 0.021 \\
\hline \multirow[t]{3}{*}{ Exchange rate } & Subsidiary & 1,453 & 0.610 & 0.958 \\
\hline & Developing & 928 & 0.413 & 1.109 \\
\hline & Developed & 525 & 0.959 & 0.424 \\
\hline \multirow[t]{3}{*}{ Concentration } & Subsidiary & 1,338 & 0.618 & 0.196 \\
\hline & Developing & 829 & 0.607 & 0.183 \\
\hline & Developed & 509 & 0.637 & 0.215 \\
\hline \multirow[t]{3}{*}{ Cost to Income } & Subsidiary & 1,332 & 0.678 & 0.207 \\
\hline & Developing & 827 & 0.701 & 0.222 \\
\hline & Developed & 505 & 0.642 & 0.175 \\
\hline \multirow[t]{3}{*}{ Deposit insurance } & Subsidiary & 109 & 0.679 & 0.469 \\
\hline & Developing & 76 & 0.645 & 0.482 \\
\hline & Developed & 33 & 0.758 & 0.435 \\
\hline
\end{tabular}




\begin{tabular}{|c|c|c|c|c|c|c|c|c|c|}
\hline \multirow{3}{*}{\multicolumn{2}{|c|}{$\begin{array}{c}1 \\
\text { subsidiary characteristics }\end{array}$}} & \multirow[b]{2}{*}{2} & \multirow[b]{2}{*}{3} & \multicolumn{3}{|c|}{ developing } & \multicolumn{3}{|c|}{ developed } \\
\hline & & & & 1 & 2 & 3 & 1 & 2 & 3 \\
\hline & & \multicolumn{8}{|c|}{ subsidiary characteristics } \\
\hline \multirow[t]{2}{*}{ Loan Loss } & 0.021 & 0.094 & 0.091 & 0.049 & 0.159 & 0.146 & -0.083 & -0.043 & -0.039 \\
\hline & {$[0.061]$} & [0.097] & {$[0.118]$} & {$[0.055]$} & {$[0.114]$} & {$[0.141]$} & {$[0.072]$} & [0.085] & {$[0.081]$} \\
\hline \multirow[t]{2}{*}{$R O E$} & 0.027 & 0.076 & 0.055 & 0.077 & 0.093 & 0.067 & -0.028 & -0.122 & -0.278 \\
\hline & [0.099] & [0.077] & [0.083] & {$[0.079]$} & {$[0.073]$} & {$[0.075]$} & {$[0.208]$} & {$[0.535]$} & {$[0.624]$} \\
\hline \multirow[t]{2}{*}{ Equity } & $-1.797 * *$ & $-2.431 * *$ & $-2.631 * *$ & -0.358 & -0.794 & -1.023 & $-3.597 * * *$ & $-4.014 * * *$ & $-3.994 * * *$ \\
\hline & {$[0.784]$} & {$[0.941]$} & [1.017] & {$[0.856]$} & [1.122] & [1.178] & [1.017] & [1.336] & [1.456] \\
\hline \multirow[t]{2}{*}{ Liquidity } & 0.163 & -0.073 & -0.045 & 0.297 & 0.008 & 0.092 & 0.118 & 0.009 & -0.012 \\
\hline & {$[0.265]$} & [0.167] & [0.181] & [0.388] & [0.304] & {$[0.321]$} & [0.148] & {$[0.158]$} & {$[0.155]$} \\
\hline \multirow[t]{2}{*}{ Size } & -0.002 & -0.080 & -0.123 & $0.080 *$ & 0.013 & -0.083 & $-0.157 *$ & $-0.269 *$ & -0.241 \\
\hline & {$[0.041]$} & [0.077] & [0.091] & [0.047] & {$[0.088]$} & [0.113] & [0.094] & {$[0.158]$} & [0.173] \\
\hline \multicolumn{10}{|l|}{ host country } \\
\hline \multirow[t]{2}{*}{ GDP growth } & $2.329 * *$ & $2.507 * *$ & $3.123 * *$ & $1.821^{*}$ & 1.711 & 2.128 & 1.062 & 4.743 & 7.991 \\
\hline & [1.066] & [1.234] & [1.437] & [1.065] & [1.169] & [1.346] & [4.627] & [6.826] & {$[6.725]$} \\
\hline \multirow{2}{*}{ Exchange rate } & $0.088 * * *$ & 0.047 & 0.152 & $0.107 * * *$ & 0.48 & $0.690 *$ & 0.024 & -0.013 & 0.336 \\
\hline & {$[0.021]$} & [0.301] & [0.342] & {$[0.028]$} & {$[0.346]$} & [0.369] & {$[0.232]$} & [0.413] & {$[0.421]$} \\
\hline \multirow{2}{*}{ Concentration } & 0.122 & 0.676 & 0.828 & 0.227 & $1.062 *$ & $1.347 *$ & 0.050 & -0.296 & -0.247 \\
\hline & [0.300] & {$[0.486]$} & {$[0.540]$} & {$[0.386]$} & [0.623] & [0.690] & [0.417] & [0.687] & [0.853] \\
\hline \multirow[t]{2}{*}{ Cost to Income } & 0.107 & 0.151 & 0.159 & 0.1 & 0.239 & 0.226 & -0.035 & -0.120 & -0.878 \\
\hline & {$[0.214]$} & [0.308] & [0.379] & {$[0.262]$} & {$[0.425]$} & [0.427] & {$[0.365]$} & [0.469] & {$[0.828]$} \\
\hline \multicolumn{10}{|c|}{ parent characteristics } \\
\hline \multirow{2}{*}{\multicolumn{2}{|c|}{ Loan Loss }} & $-0.398 * *$ & $-0.634 * *$ & & $-0.525 * *$ & $-0.630 *$ & & -0.156 & $-0.564 *$ \\
\hline & & {$[0.179]$} & {$[0.289]$} & & {$[0.258]$} & {$[0.372]$} & & [0.187] & {$[0.311]$} \\
\hline \multirow{2}{*}{\multicolumn{2}{|c|}{$R O E$}} & -0.310 & 0.107 & & -0.597 & -0.172 & & 0.042 & 0.234 \\
\hline & & {$[0.234]$} & {$[0.634]$} & & {$[0.452]$} & {$[0.836]$} & & [0.229] & {$[0.925]$} \\
\hline Equity & & 0.436 & 0.532 & & 0.383 & 0.506 & & 0.799 & -0.133 \\
\hline & & [1.448] & {$[1.514]$} & & [2.153] & {$[2.175]$} & & [1.216] & [1.487] \\
\hline Liquidity & & 0.555 & 0.426 & & 0.519 & -0.019 & & 1.138 & 1.634 \\
\hline & & {$[0.468]$} & [0.603] & & {$[0.623]$} & {$[0.814]$} & & [0.964] & [1.038] \\
\hline home country & & & & & & & & & \\
\hline GDP growth & & -3.268 & $-9.049 * *$ & & -4.549 & -7.134 & & -4.591 & $-17.422 * *$ \\
\hline & & [2.485] & [4.188] & & {$[3.478]$} & [5.033] & & [4.076] & {$[7.713]$} \\
\hline Crisis & & & $0.604 *$ & & & 0.335 & & & $1.242 *$ \\
\hline & & & [0.361] & & & {$[0.358]$} & & & {$[0.640]$} \\
\hline interactions & & & & & & & & & \\
\hline crisis $* P \_L o a n$ Los & & & -0.428 & & & -0.285 & & & -1.031 \\
\hline & & & {$[0.590]$} & & & [0.668] & & & {$[0.857]$} \\
\hline crisis $* P \_R O E$ & & & -0.614 & & & 0.236 & & & -1.974 \\
\hline & & & {$[1.022]$} & & & [1.231] & & & [1.359] \\
\hline crisis $* P \_E q u i t y$ & & & -5.662 & & & -4.434 & & & $-9.955^{*}$ \\
\hline & & & [4.661] & & & [6.452] & & & [5.787] \\
\hline crisis $* P \_$Liquidity & & & -0.482 & & & 1.070 & & & $-2.843 * *$ \\
\hline & & & {$[1.465]$} & & & [1.937] & & & {$[1.357]$} \\
\hline Constant & 0.005 & 0.418 & 0.679 & -0.783 & -0.776 & -0.314 & $1.673^{*}$ & $2.752 *$ & 2.92 \\
\hline & {$[0.420]$} & {$[0.800]$} & [0.877] & [0.477] & [0.901] & [0.964] & [0.957] & [1.630] & [1.884] \\
\hline Observations & 1674 & 978 & 881 & 1059 & 605 & 566 & 622 & 374 & 316 \\
\hline Number of banks & 286 & 185 & 169 & 0.012 & 0.021 & 0.031 & 105 & 75 & 65 \\
\hline R-squared & 0.015 & 0.025 & 0.034 & 184 & 111 & 105 & 0.044 & 0.062 & 0.083 \\
\hline
\end{tabular}

The table reports the fixed effects panel estimation results. The dependent variable is $\Delta$ Loans, yearly change in loans measured as the first difference of the log of total loans. Third specifications exclude the Asian parents. All variable definitions are presented in Table 1. Robust standard errors are in parentheses. ***,**, * significant at 1\%, 5\% and 10\%, respectively. 
Table 4 Loan Growth and Interbank Dependency

\begin{tabular}{|c|c|c|c|c|c|c|c|c|}
\hline & \multicolumn{4}{|c|}{ Interbank $<1$} & \multicolumn{4}{|c|}{ Interbank>1 } \\
\hline & 1 & 2 & 3 & 4 & 1 & 2 & 3 & 4 \\
\hline \multicolumn{9}{|c|}{ subsidiary characteristics } \\
\hline \multirow[t]{2}{*}{ Loan Loss } & -0.014 & -0.123 & -0.177 & -0.151 & 0.024 & 0.141 & 0.100 & 0.068 \\
\hline & {$[0.063]$} & {$[0.121]$} & {$[0.160]$} & {$[0.153]$} & {$[0.050]$} & {$[0.123]$} & {$[0.170]$} & [0.089] \\
\hline \multirow[t]{2}{*}{$R O E$} & 0.016 & 0.045 & 0.069 & -0.011 & 0.158 & 0.004 & -0.115 & 0.106 \\
\hline & {$[0.066]$} & {$[0.063]$} & {$[0.075]$} & {$[0.063]$} & {$[0.138]$} & {$[0.150]$} & {$[0.178]$} & {$[0.238]$} \\
\hline \multirow[t]{2}{*}{ Equity } & 0.940 & 1.237 & 0.548 & 0.911 & $-2.330 * *$ & -1.919 & -2.035 & -0.561 \\
\hline & [1.111] & {$[2.633]$} & {$[2.647]$} & {$[1.801]$} & [1.169] & {$[1.445]$} & {$[1.566]$} & {$[1.256]$} \\
\hline \multirow[t]{2}{*}{ Liquidity } & 0.113 & 0.019 & 0.013 & & 0.679 & 0.213 & 0.232 & \\
\hline & {$[0.343]$} & {$[0.420]$} & {$[0.501]$} & & {$[0.588]$} & [0.669] & {$[0.712]$} & \\
\hline \multirow[t]{2}{*}{ Size } & 0.142 & 0.017 & -0.110 & 0.048 & 0.025 & 0.054 & -0.077 & -0.082 \\
\hline & {$[0.096]$} & {$[0.145]$} & {$[0.212]$} & {$[0.192]$} & {$[0.082]$} & {$[0.161]$} & [0.203] & {$[0.108]$} \\
\hline \multicolumn{9}{|l|}{ host country } \\
\hline \multirow[t]{2}{*}{ GDP growth } & $4.182 * *$ & 4.462 & 4.938 & $5.654 *$ & -0.322 & -0.682 & -1.024 & 0.885 \\
\hline & {$[1.860]$} & [2.893] & [3.101] & [2.946] & [1.636] & {$[1.576]$} & {$[1.850]$} & [1.672] \\
\hline \multirow[t]{2}{*}{ Exchange rate } & 0.182 & 0.176 & -0.165 & -0.215 & $0.081 * * *$ & 0.433 & 0.757 & 0.417 \\
\hline & {$[0.540]$} & {$[0.626]$} & {$[0.744]$} & {$[0.964]$} & {$[0.027]$} & {$[0.378]$} & [0.479] & {$[0.345]$} \\
\hline \multirow[t]{2}{*}{ Concentration } & 1.192 & 2.332 & 2.098 & $1.754 *$ & -0.548 & 0.011 & -0.244 & -1.083 \\
\hline & {$[0.947]$} & [1.564] & [1.608] & {$[0.944]$} & {$[0.515]$} & {$[0.845]$} & [1.021] & {$[0.870]$} \\
\hline \multirow[t]{2}{*}{ Cost to Income } & 0.298 & 0.338 & 0.202 & 0.295 & 0.07 & 0.155 & 0.078 & 0.064 \\
\hline & {$[0.394]$} & {$[0.740]$} & {$[0.677]$} & {$[0.462]$} & {$[0.331]$} & {$[0.525]$} & {$[0.558]$} & {$[0.641]$} \\
\hline \multicolumn{9}{|c|}{ parent characteristics } \\
\hline \multirow[t]{2}{*}{ Loan Loss } & & $-0.858 * *$ & -0.632 & $-0.539 *$ & & -0.677 & -0.704 & -0.613 \\
\hline & & {$[0.349]$} & [0.449] & {$[0.277]$} & & {$[0.437]$} & {$[0.627]$} & [0.464] \\
\hline \multirow[t]{2}{*}{$R O E$} & & -0.165 & -0.567 & -0.264 & & $-1.353^{*}$ & 0.800 & 0.245 \\
\hline & & {$[0.636]$} & {$[1.034]$} & {$[0.732]$} & & {$[0.783]$} & [1.442] & {$[0.780]$} \\
\hline \multirow[t]{2}{*}{ Equity } & & -7.066 & -8.713 & -3.138 & & 0.849 & 0.080 & 0.711 \\
\hline & & {$[4.825]$} & [6.603] & {$[6.281]$} & & {$[2.310]$} & [2.439] & [2.130] \\
\hline \multirow[t]{2}{*}{ Liquidity } & & -1.117 & -1.792 & & & 0.502 & -0.193 & \\
\hline & & {$[1.495]$} & {$[1.536]$} & & & {$[0.805]$} & [0.962] & \\
\hline Interbank & & & & -0.082 & & & & -0.017 \\
\hline & & & & {$[0.101]$} & & & & {$[0.088]$} \\
\hline home country & & & & & & & & \\
\hline GDP growth & & -3.070 & -1.738 & -3.230 & & -3.791 & -11.090 & -4.157 \\
\hline & & {$[7.390]$} & [8.138] & [9.684] & & {$[5.355]$} & [8.737] & [7.433] \\
\hline Crisis & & & 0.522 & 0.708 & & & 0.240 & -0.354 \\
\hline & & & {$[0.703]$} & [1.155] & & & [0.473] & [0.442] \\
\hline interactions & & & & & & & & \\
\hline Crisis $* P \_L o a n$ Los & & & -2.480 & $-2.517 * *$ & & & -0.510 & $1.941 *$ \\
\hline & & & {$[1.551]$} & [0.994] & & & [0.719] & [1.006] \\
\hline Crisis*P_ROE & & & -0.758 & $-2.568 * *$ & & & -2.793 & -1.141 \\
\hline & & & [1.911] & [1.182] & & & [1.969] & [1.561] \\
\hline Crisis $* P \_$Equity & & & 0.304 & -7.046 & & & 0.895 & -0.630 \\
\hline & & & [14.757] & {$[12.461]$} & & & [3.853] & [3.646] \\
\hline Crisis $* P \_$Liquidity & & & 0.703 & & & & 1.981 & \\
\hline & & & [4.175] & & & & [1.674] & \\
\hline Crisis $* P$ Interbank & & & & 0.540 & & & & 0.337 \\
\hline & & & & {$[0.965]$} & & & & {$[0.338]$} \\
\hline Constant & $-2.156 * *$ & -1.170 & 0.312 & -1.282 & 0.376 & -0.031 & 0.925 & 1.161 \\
\hline & {$[0.865]$} & {$[1.621]$} & [1.869] & {$[1.381]$} & {$[0.777]$} & [1.397] & [1.668] & {$[0.921]$} \\
\hline Observations & 421 & 276 & 271 & 297 & 638 & 329 & 295 & 387 \\
\hline Number of banks & 120 & 77 & 74 & 85 & 149 & 86 & 80 & 85 \\
\hline R-squared & 0.035 & 0.046 & 0.06 & 0.081 & 0.027 & 0.036 & 0.046 & 0.027 \\
\hline
\end{tabular}

The table reports the fixed effects panel estimation results. The dependent variable is $\Delta$ Loans, yearly change in loans measured as the first difference of the log of total loans. The first (second) four specifications report the results for the sample with an interbank ratio below (above) its median. Third and fourth specifications in both groups exclude the Asian parents. All variable definitions are presented in Table 1. Robust standard errors are in parentheses. $* * *$ significant at $1 \%$, ** significant at $5 \%$, significant at $10 \%$. 
Table 5

Market Discipline

\begin{tabular}{|c|c|c|c|c|c|c|c|c|c|c|c|c|}
\hline & \multicolumn{5}{|c|}{$\Delta$ Time Deposits } & \multicolumn{3}{|c|}{$\Delta$ Bank Deposits } & \multicolumn{4}{|c|}{ Interest Rate } \\
\hline & FE & FE & $\mathrm{RE}$ & FE & $\mathrm{RE}$ & $\mathrm{FE}$ & FE & FE & FE & FE & $\mathrm{RE}$ & FE \\
\hline \multicolumn{13}{|c|}{ subsidiary characteristics } \\
\hline \multirow[t]{2}{*}{ Loan Loss } & 0.013 & -0.015 & -0.057 & -0.053 & -0.07 & 0.075 & 0.122 & 0.131 & $0.011 *$ & $\mathbf{0 . 0 2 0} * * *$ & $0.021 * * *$ & $0.025 * * *$ \\
\hline & {$[0.049]$} & {$[0.084]$} & {$[0.058]$} & [0.091] & {$[0.069]$} & [0.124] & {$[0.184]$} & {$[0.212]$} & {$[0.006]$} & [0.007] & {$[0.006]$} & {$[0.007]$} \\
\hline \multirow[t]{2}{*}{$R O E$} & 0.004 & -0.179 & -0.15 & $-0.275^{*}$ & $-0.252 *$ & -0.16 & $-0.361 * * *$ & $-0.369 * * *$ & 0.006 & -0.016 & -0.019 & -0.019 \\
\hline & {$[0.057]$} & {$[0.140]$} & {$[0.120]$} & [0.147] & {$[0.146]$} & {$[0.118]$} & [0.107] & [0.099] & {$[0.012]$} & [0.017] & {$[0.017]$} & {$[0.020]$} \\
\hline \multirow[t]{2}{*}{ Equity } & -0.256 & 1.556 & 0.657 & 1.886 & 0.714 & $-0.931 *$ & -0.839 & $-1.253 *$ & 0.05 & -0.033 & 0.027 & 0.001 \\
\hline & {$[1.016]$} & [1.279] & {$[0.713]$} & [1.360] & {$[0.784]$} & {$[0.527]$} & {$[0.615]$} & {$[0.704]$} & [0.069] & {$[0.071]$} & [0.099] & [0.079] \\
\hline \multirow[t]{2}{*}{ Liquidity } & $0.400 *$ & -0.099 & -0.267 & -0.071 & -0.277 & 0.000 & -0.517 & -0.414 & $-0.113 * *$ & 0.004 & 0.019 & 0.004 \\
\hline & {$[0.219]$} & {$[0.590]$} & {$[0.312]$} & [0.611] & {$[0.338]$} & [0.182] & {$[0.324]$} & [0.315] & [0.053] & {$[0.018]$} & {$[0.027]$} & [0.019] \\
\hline \multirow[t]{2}{*}{ Size } & -0.072 & 0.110 & 0.012 & 0.203 & 0.011 & 0.007 & -0.085 & -0.091 & $-0.012 *$ & $-0.019 * * *$ & -0.006 & $-0.013 *$ \\
\hline & [0.083] & {$[0.125]$} & [0.034] & [0.149] & {$[0.044]$} & {$[0.070]$} & {$[0.120]$} & {$[0.137]$} & [0.007] & [0.007] & {$[0.004]$} & {$[0.007]$} \\
\hline \multicolumn{13}{|l|}{ host country } \\
\hline \multirow[t]{2}{*}{ GDP growth } & $3.680 * * *$ & 2.818* & $3.524 * *$ & 2.824 & 3.580 ** & 2.838 & $5.667 *$ & $5.887 *$ & $-0.608 * *$ & $-0.315^{* * *}$ & $-0.352 * * *$ & $-\mathbf{0 . 3 0 3} * *$ \\
\hline & {$[1.065]$} & [1.631] & [1.493] & [1.955] & [1.711] & [2.214] & [3.146] & [3.087] & [0.259] & {$[0.112]$} & {$[0.124]$} & {$[0.126]$} \\
\hline \multirow[t]{2}{*}{ Exchange rate } & $0.106 * * *$ & 0.151 & 0.014 & 0.031 & 0.050 & $0.119 * * *$ & 0.151 & 0.071 & -0.002 & -0.023 & -0.008 & -0.007 \\
\hline & [0.033] & [0.287] & [0.105] & [0.323] & {$[0.117]$} & {$[0.013]$} & {$[0.516]$} & {$[0.537]$} & {$[0.004]$} & [0.025] & {$[0.015]$} & [0.029] \\
\hline \multirow[t]{2}{*}{ Concentration } & -0.143 & 0.946 & 0.142 & $1.678^{*}$ & 0.152 & -0.115 & -0.050 & 0.193 & 0.061 & 0.008 & 0.031 & 0.013 \\
\hline & [0.832] & {$[0.778]$} & {$[0.287]$} & [0.909] & {$[0.326]$} & [0.676] & [1.080] & [1.109] & {$[0.084]$} & {$[0.052]$} & {$[0.036]$} & {$[0.057]$} \\
\hline \multirow[t]{2}{*}{ Developed } & & & 0.080 & & 0.062 & & & & & & $-0.063^{* * *}$ & \\
\hline & & & {$[0.125]$} & & {$[0.144]$} & & & & & & {$[0.023]$} & \\
\hline \multirow[t]{2}{*}{ Deposit insurance } & & & 0.190 & & 0.145 & & & & & & -0.015 & \\
\hline & & & {$[0.137]$} & & {$[0.241]$} & & & & & & {$[0.039]$} & \\
\hline \multicolumn{13}{|c|}{ parent characteristics } \\
\hline \multirow[t]{2}{*}{ Loan Loss } & & -0.402 & -0.240 & $-1.094 * *$ & -0.338 & & 0.210 & 0.247 & & $0.025^{*}$ & 0.011 & $0.048^{* *}$ \\
\hline & & {$[0.311]$} & {$[0.169]$} & {$[0.473]$} & {$[0.263]$} & & {$[0.406]$} & {$[0.448]$} & & {$[0.015]$} & {$[0.012]$} & {$[0.023]$} \\
\hline \multirow[t]{2}{*}{$R O E$} & & -0.346 & -0.107 & -1.369 & -0.517 & & 0.152 & -2.461 & & 0.022 & 0.006 & 0.053 \\
\hline & & {$[0.306]$} & {$[0.267]$} & [1.269] & {$[0.835]$} & & {$[0.447]$} & {$[1.490]$} & & {$[0.020]$} & {$[0.018]$} & {$[0.075]$} \\
\hline \multirow[t]{2}{*}{ Equity } & & -1.054 & -1.974 & -1.930 & $-2.800 *$ & & 0.730 & 0.792 & & 0.155 & 0.090 & 0.183 \\
\hline & & {$[1.722]$} & [1.314] & [1.767] & {$[1.429]$} & & {$[1.360]$} & {$[1.246]$} & & [0.159] & {$[0.165]$} & [0.162] \\
\hline \multirow[t]{2}{*}{ Liquidity } & & 0.709 & -0.099 & $1.622 * *$ & 0.226 & & 0.596 & $2.294 * *$ & & -0.059 & 0.017 & -0.075 \\
\hline & & {$[0.779]$} & {$[0.532]$} & {$[0.800]$} & {$[0.610]$} & & [1.114] & [1.137] & & {$[0.068]$} & {$[0.055]$} & {$[0.075]$} \\
\hline
\end{tabular}


Table 5 continued

\begin{tabular}{|c|c|c|c|c|c|c|c|c|c|c|c|c|}
\hline & \multicolumn{5}{|c|}{$\Delta$ Time Deposits } & \multicolumn{3}{|c|}{$\Delta$ Bank Deposits } & \multicolumn{4}{|c|}{ Interest Rate } \\
\hline & FE & $\mathrm{FE}$ & $\mathrm{RE}$ & $\mathrm{FE}$ & $\mathrm{RE}$ & $\mathrm{FE}$ & $\mathrm{FE}$ & FE & $\mathrm{FE}$ & $\mathrm{FE}$ & $\mathrm{RE}$ & $\mathrm{FE}$ \\
\hline \multicolumn{13}{|l|}{ home country } \\
\hline GDP growth & & $\begin{array}{c}\mathbf{8 . 2 5 1} * * * \\
{[2.758]}\end{array}$ & $\begin{array}{l}\mathbf{6 . 9 1 0} * * \\
{[2.772]}\end{array}$ & $\begin{array}{c}7.189 \\
{[4.852]}\end{array}$ & $\begin{array}{l}\text { 7.350* } \\
{[3.855]}\end{array}$ & & $\begin{array}{c}-6.344 \\
{[4.487]}\end{array}$ & $\begin{array}{l}-5.729 \\
{[6.594]}\end{array}$ & & $\begin{array}{c}-0.104 \\
{[0.255]}\end{array}$ & $\begin{array}{c}-0.117 \\
{[0.253]}\end{array}$ & $\begin{array}{c}-0.199 \\
{[0.350]}\end{array}$ \\
\hline Crisis & & & & $\begin{array}{c}-0.745 \\
{[0.528]}\end{array}$ & $\begin{array}{c}-0.298 \\
{[0.399]}\end{array}$ & & & $\begin{array}{l}\mathbf{1 . 5 0 1} * * \\
{[0.600]}\end{array}$ & & & & $\begin{array}{c}-0.022 \\
{[0.029]}\end{array}$ \\
\hline \multicolumn{13}{|l|}{ interactions } \\
\hline Crisis*P_Loan Loss & & & & $\begin{array}{c}0.810 \\
{[1.018]}\end{array}$ & $\begin{array}{c}0.249 \\
{[0.759]}\end{array}$ & & & $\begin{array}{c}\mathbf{- 1 . 9 6 2 * *} \\
{[0.975]}\end{array}$ & & & & $\begin{array}{c}\mathbf{0 . 1 2 5} \text { ** } \\
{[0.062]}\end{array}$ \\
\hline Crisis*P_ROE & & & & $\begin{array}{l}\mathbf{2 . 8 2 2} * \\
{[1.444]}\end{array}$ & $\begin{array}{c}1.412 \\
{[0.969]}\end{array}$ & & & $\begin{array}{c}1.411 \\
{[1.748]}\end{array}$ & & & & $\begin{array}{c}-0.002 \\
{[0.074]}\end{array}$ \\
\hline Crisis*P_Equity & & & & $\begin{array}{c}5.421 \\
{[3.733]}\end{array}$ & $\begin{array}{c}2.923 \\
{[3.485]}\end{array}$ & & & $\begin{array}{c}-1.831 \\
{[5.223]}\end{array}$ & & & & $\begin{array}{c}-0.138 \\
{[0.293]}\end{array}$ \\
\hline Crisis $* P \_$Liquidity & & & & $\begin{array}{l}-1.367 \\
{[1.602]}\end{array}$ & $\begin{array}{c}-0.673 \\
{[1.327]}\end{array}$ & & & $\begin{array}{c}\mathbf{- 9 . 1 4 3} * * * \\
{[2.965]}\end{array}$ & & & & $\begin{array}{c}0.010 \\
{[0.078]}\end{array}$ \\
\hline Constant & $\begin{array}{c}0.397 \\
{[0.950]}\end{array}$ & $\begin{array}{l}-1.849^{*} \\
{[0.975]}\end{array}$ & $\begin{array}{c}-0.529 \\
{[0.356]}\end{array}$ & $\begin{array}{c}-2.763 * * \\
{[1.125]}\end{array}$ & $\begin{array}{c}-0.449 \\
{[0.439]}\end{array}$ & $\begin{array}{c}-0.001 \\
{[0.687]}\end{array}$ & $\begin{array}{c}0.593 \\
{[1.045]}\end{array}$ & $\begin{array}{c}0.565 \\
{[1.263]}\end{array}$ & $\begin{array}{c}0.186 * * \\
{[0.084]}\end{array}$ & $\begin{array}{c}0.264 * * * \\
{[0.054]}\end{array}$ & $\begin{array}{c}0.179 * * * \\
{[0.057]}\end{array}$ & $\begin{array}{c}0.211 * * * \\
{[0.061]}\end{array}$ \\
\hline Observations & 1254 & 671 & 671 & 608 & 608 & 1328 & 793 & 743 & 1664 & 971 & 971 & 880 \\
\hline Number of banks & 239 & 148 & 148 & 136 & 136 & 250 & 164 & 154 & 286 & 186 & 186 & 171 \\
\hline R-squared & 0.022 & 0.034 & 0.063 & 0.050 & 0.065 & 0.008 & 0.019 & 0.048 & 0.057 & 0.030 & 0.052 & 0.038 \\
\hline Hausman test & & & & & & & & & & & & \\
\hline Chi2 & & & 7.050 & & 13.720 & & & & & & 11.560 & \\
\hline p-value & & & 0.900 & & 0.747 & & & & & & 0.564 & \\
\hline
\end{tabular}

The table reports the fixed effects and random effects panel estimation results. The dependent variables are $\Delta$ Time Deposits, yearly change in time deposits, $\Delta$ Bank Deposits, yearly change in bank deposits and Interest Rates, measured as total interest rate expenses to total interest bearing deposits. The last two specifications in the first panel and the last specifications in the other panels exclude the Asian parents. All variable definitions are presented in Table 1. Robust standard errors are in parentheses. *** significant at $1 \%, * *$ significant at $5 \%$, $*$ significant at $10 \%$ 


\begin{tabular}{|c|c|c|c|c|c|c|c|c|c|}
\hline & \multicolumn{3}{|c|}{$\Delta$ Time Deposits } & \multicolumn{3}{|c|}{$\Delta$ Bank Deposits } & \multicolumn{3}{|c|}{ Interest Rate } \\
\hline & 1 & 2 & 3 & 1 & 2 & 3 & 1 & 2 & 3 \\
\hline \multicolumn{10}{|c|}{ subsidiary characteristics } \\
\hline \multirow[t]{2}{*}{ Loan Loss } & -0.015 & -0.098 & $-0.154 *$ & 0.133 & 0.342 & 0.331 & 0.009 & $0.023 * *$ & $0.030 * * *$ \\
\hline & {$[0.042]$} & [0.081] & {$[0.090]$} & {$[0.173]$} & {$[0.280]$} & [0.342] & [0.006] & {$[0.010]$} & {$[0.011]$} \\
\hline \multirow[t]{2}{*}{$R O E$} & -0.028 & -0.266 & $-0.429 * *$ & -0.122 & $-0.292 * * *$ & $-0.299 * * *$ & 0.006 & -0.019 & -0.021 \\
\hline & {$[0.052]$} & {$[0.172]$} & {$[0.165]$} & [0.122] & {$[0.090]$} & {$[0.085]$} & [0.012] & [0.018] & {$[0.021]$} \\
\hline \multirow[t]{2}{*}{ Equity } & -0.751 & 1.669 & 2.351 & -0.794 & -0.21 & -1.092 & 0.101 & -0.007 & 0.029 \\
\hline & [1.125] & [1.633] & [1.735] & {$[0.772]$} & [1.047] & [1.083] & [0.090] & [0.115] & [0.127] \\
\hline \multirow[t]{2}{*}{ Liquidity } & 0.44 & 0.835 & 0.818 & -0.19 & -0.205 & -0.027 & -0.002 & 0.008 & 0.01 \\
\hline & {$[0.371]$} & {$[0.570]$} & {$[0.613]$} & {$[0.378]$} & [0.596] & [0.592] & [0.030] & {$[0.030]$} & {$[0.030]$} \\
\hline \multirow[t]{2}{*}{ Size } & -0.107 & 0.196 & $0.355^{*}$ & -0.019 & -0.103 & -0.234 & -0.006 & $-0.021 * *$ & -0.013 \\
\hline & {$[0.126]$} & {$[0.176]$} & [0.204] & {$[0.088]$} & [0.153] & [0.167] & [0.009] & [0.009] & [0.009] \\
\hline \multicolumn{10}{|l|}{ host country } \\
\hline \multirow[t]{2}{*}{ GDP growth } & 3.508**** & 1.383 & 1.585 & 3.28 & $6.410 *$ & 5.978* & $-0.714 * *$ & $-0.361 * * *$ & $-0.341 * *$ \\
\hline & [1.099] & [1.319] & {$[1.555]$} & [2.403] & [3.448] & [3.128] & {$[0.285]$} & {$[0.121]$} & {$[0.135]$} \\
\hline \multirow[t]{2}{*}{ Exchange rate } & $0.095 * * *$ & 0.313 & 0.192 & $0.114 * * *$ & 0.961 & 0.775 & -0.001 & -0.043 & -0.023 \\
\hline & [0.027] & [0.294] & {$[0.351]$} & {$[0.013]$} & [0.749] & [0.860] & [0.003] & [0.046] & {$[0.047]$} \\
\hline \multirow[t]{2}{*}{ Concentration } & -0.65 & 1.269 & 1.940 & -0.607 & -0.068 & 0.662 & 0.133 & -0.018 & 0.014 \\
\hline & [1.344] & {$[1.058]$} & [1.299] & {$[0.884]$} & [1.719] & [1.530] & [0.115] & {$[0.073]$} & [0.083] \\
\hline \multicolumn{10}{|c|}{ parent characteristics } \\
\hline \multirow[t]{2}{*}{ Loan Loss } & & -0.288 & $-1.300^{*}$ & & 0.295 & 0.387 & & $0.037 *$ & $0.054 *$ \\
\hline & & [0.411] & {$[0.725]$} & & {$[0.585]$} & {$[0.542]$} & & [0.021] & {$[0.031]$} \\
\hline \multirow[t]{2}{*}{$R O E$} & & -0.16 & -1.553 & & 0.314 & -2.582 & & 0.041 & 0.133 \\
\hline & & {$[0.530]$} & [1.613] & & [1.122] & [1.641] & & {$[0.035]$} & [0.099] \\
\hline \multirow[t]{2}{*}{ Equity } & & -2.802 & -3.954 & & 2.693 & 2.325 & & 0.231 & 0.283 \\
\hline & & [2.790] & [2.858] & & [2.051] & [1.524] & & {$[0.245]$} & {$[0.247]$} \\
\hline \multirow[t]{2}{*}{ Liquidity } & & 1.356 & 1.987 & & -0.030 & 1.856 & & -0.037 & -0.072 \\
\hline & & [1.296] & [1.312] & & [1.567] & [1.443] & & {$[0.082]$} & [0.094] \\
\hline \multicolumn{10}{|l|}{ home country } \\
\hline \multirow[t]{2}{*}{ GDP growth } & & $13.669 * * *$ & $12.692 * *$ & & $-13.376^{*}$ & -8.797 & & -0.146 & -0.402 \\
\hline & & [3.969] & {$[5.270]$} & & {$[7.621]$} & [7.949] & & {$[0.534]$} & {$[0.537]$} \\
\hline Crisis & & & $-1.143 * *$ & & & $1.878 * *$ & & & 0.005 \\
\hline & & & {$[0.484]$} & & & [0.904] & & & {$[0.046]$} \\
\hline interactions & & & & & & & & & \\
\hline Crisis*P_Loan Loss & & & 2.009* & & & -1.674 & & & 0.128 \\
\hline & & & [1.111] & & & {$[1.121]$} & & & {$[0.084]$} \\
\hline Crisis*P_ROE & & & $3.582 * *$ & & & 3.084 & & & -0.132 \\
\hline & & & [1.771] & & & [2.457] & & & {$[0.113]$} \\
\hline Crisis ${ }^{*} P \_$Equity & & & 4.158 & & & -0.91 & & & -0.370 \\
\hline & & & [4.366] & & & [8.270] & & & {$[0.501]$} \\
\hline Crisis $* P \_$Liquidity & & & 0.177 & & & $-11.284 * * *$ & & & -0.066 \\
\hline & & & [1.351] & & & {$[3.847]$} & & & {$[0.160]$} \\
\hline Constant & 0.955 & $-2.865 * *$ & $-4.057 * *$ & 0.493 & 0.277 & 0.789 & 0.103 & $0.299 * * *$ & $0.221 * *$ \\
\hline & [1.489] & [1.302] & {$[1.561]$} & {$[0.810]$} & [1.596] & [1.715] & {$[0.100]$} & {$[0.075]$} & {$[0.087]$} \\
\hline Observations & 798 & 424 & 387 & 847 & 497 & 481 & 1047 & 613 & 576 \\
\hline Number of banks & 161 & 96 & 90 & 162 & 102 & 98 & 185 & 114 & 108 \\
\hline R-squared & 0.025 & 0.055 & 0.081 & 0.011 & 0.033 & 0.078 & 0.034 & 0.037 & 0.049 \\
\hline
\end{tabular}

The table reports the fixed effects panel estimation results for developing countries. The dependent variables are $\Delta$ Time Deposits, yearly change in time deposits, $\Delta$ Bank Deposits, yearly change in bank deposits and Interest Rates, measured as total interest rate expenses to total interest bearing deposits. The third specification in each panel excludes the Asian parents. All variable definitions are presented in Table 1. Robust standard errors are in parentheses. *** significant at $1 \%$, ** significant at $5 \%$, significant at $10 \%$ 
Table $7 \quad$ Market Discipline in Developed Countries

\begin{tabular}{|c|c|c|c|c|c|c|c|c|c|}
\hline & \multicolumn{3}{|c|}{$\Delta$ Time Deposits } & \multicolumn{3}{|c|}{$\Delta$ Bank Deposits } & \multicolumn{3}{|c|}{ Interest Rate } \\
\hline & 1 & 2 & 3 & 1 & 2 & 3 & 1 & 2 & 3 \\
\hline \multicolumn{10}{|c|}{ subsidiary characteristics (lagged) } \\
\hline Loan Loss & $\begin{array}{c}0.158 \\
{[0.160]}\end{array}$ & $\begin{array}{c}0.125 \\
{[0.232]}\end{array}$ & $\begin{array}{c}0.095 \\
{[0.251]}\end{array}$ & $\begin{array}{c}-0.034 \\
{[0.086]}\end{array}$ & $\begin{array}{c}-0.146 \\
{[0.091]}\end{array}$ & $\begin{array}{c}-0.152 \\
{[0.098]}\end{array}$ & $\begin{array}{c}\mathbf{0 . 0 1 3} * * * \\
{[0.005]}\end{array}$ & $\begin{array}{c}\mathbf{0 . 0 1 5}^{* * *} * \\
{[0.004]}\end{array}$ & $\begin{array}{c}\mathbf{0 . 0 1 3}^{* * * *} \\
{[0.005]}\end{array}$ \\
\hline$R O E$ & $\begin{array}{c}\mathbf{0 . 9 9 3} * \\
{[0.579]}\end{array}$ & $\begin{array}{c}0.16 \\
{[0.560]}\end{array}$ & $\begin{array}{c}-0.071 \\
{[0.607]}\end{array}$ & $\begin{array}{c}-0.565 \\
{[0.565]}\end{array}$ & $\begin{array}{c}-0.931 \\
{[0.565]}\end{array}$ & $\begin{array}{c}-1.201 \\
{[0.806]}\end{array}$ & $\begin{array}{c}0.039 \\
{[0.039]}\end{array}$ & $\begin{array}{l}\text { 0.078* } \\
{[0.039]}\end{array}$ & $\begin{array}{c}0.055 \\
{[0.040]}\end{array}$ \\
\hline Equity & $\begin{array}{c}1.175 \\
{[1.886]}\end{array}$ & $\begin{array}{c}\mathbf{3 . 6 8 9} * * * \\
{[1.299]}\end{array}$ & $\begin{array}{c}\mathbf{2 . 9 5 7 *} \\
{[1.691]}\end{array}$ & $\begin{array}{c}-1.311 \\
{[1.084]}\end{array}$ & $\begin{array}{c}-0.468 \\
{[0.984]}\end{array}$ & $\begin{array}{c}-0.316 \\
{[1.166]}\end{array}$ & $\begin{array}{c}0.025 \\
{[0.089]}\end{array}$ & $\begin{array}{c}-0.078 \\
{[0.064]}\end{array}$ & $\begin{array}{c}-0.02 \\
{[0.034]}\end{array}$ \\
\hline Liquidity & $\begin{array}{c}0.173 \\
{[0.273]}\end{array}$ & $\begin{array}{c}\mathbf{- 1 . 3 4 1} * * * \\
{[0.440]}\end{array}$ & $\begin{array}{c}\mathbf{- 1 . 1 0 0} * \\
{[0.568]}\end{array}$ & $\begin{array}{c}0.105 \\
{[0.194]}\end{array}$ & $\begin{array}{c}-0.598 \\
{[0.471]}\end{array}$ & $\begin{array}{c}-0.435 \\
{[0.419]}\end{array}$ & $\begin{array}{c}\mathbf{- 0 . 1 5 6} * * * \\
{[0.044]}\end{array}$ & $\begin{array}{c}0.001 \\
{[0.013]}\end{array}$ & $\begin{array}{c}0.000 \\
{[0.012]}\end{array}$ \\
\hline Size & $\begin{array}{c}-0.054 \\
{[0.105]}\end{array}$ & $\begin{array}{c}0.041 \\
{[0.106]}\end{array}$ & $\begin{array}{c}0.007 \\
{[0.127]}\end{array}$ & $\begin{array}{c}0.033 \\
{[0.151]}\end{array}$ & $\begin{array}{c}0.062 \\
{[0.239]}\end{array}$ & $\begin{array}{c}0.221 \\
{[0.272]}\end{array}$ & $\begin{array}{c}-0.009 \\
{[0.006]}\end{array}$ & $\begin{array}{c}-0.012 \\
{[0.009]}\end{array}$ & $\begin{array}{l}-0.003 \\
{[0.005]}\end{array}$ \\
\hline \multicolumn{10}{|l|}{ host country } \\
\hline GDP growth & $\begin{array}{c}6.159 \\
{[3.955]}\end{array}$ & $\begin{array}{c}8.522 \\
{[6.824]}\end{array}$ & $\begin{array}{c}9.122 \\
{[7.336]}\end{array}$ & $\begin{array}{l}-0.875 \\
{[3.644]}\end{array}$ & $\begin{array}{c}2.333 \\
{[7.382]}\end{array}$ & $\begin{array}{c}2.347 \\
{[12.550]}\end{array}$ & $\begin{array}{c}-0.348 \\
{[0.222]}\end{array}$ & $\begin{array}{c}-0.091 \\
{[0.152]}\end{array}$ & $\begin{array}{c}-0.048 \\
{[0.213]}\end{array}$ \\
\hline Exchange rate & $\begin{array}{c}0.428 \\
{[0.441]}\end{array}$ & $\begin{array}{c}-0.223 \\
{[0.597]}\end{array}$ & $\begin{array}{c}-0.55 \\
{[0.680]}\end{array}$ & $\begin{array}{c}0.21 \\
{[0.457]}\end{array}$ & $\begin{array}{c}-0.747 \\
{[0.601]}\end{array}$ & $\begin{array}{c}-0.129 \\
{[0.674]}\end{array}$ & $\begin{array}{c}0.001 \\
{[0.020]}\end{array}$ & $\begin{array}{c}\mathbf{0 . 0 3 0}^{* *} \\
{[0.015]}\end{array}$ & $\begin{array}{c}0.022 \\
{[0.014]}\end{array}$ \\
\hline Concentration & $\begin{array}{c}0.710 \\
{[0.613]}\end{array}$ & $\begin{array}{c}0.574 \\
{[1.061]}\end{array}$ & $\begin{array}{c}1.278 \\
{[1.520]}\end{array}$ & $\begin{array}{c}0.595 \\
{[0.989]}\end{array}$ & $\begin{array}{c}-0.011 \\
{[0.915]}\end{array}$ & $\begin{array}{c}-0.63 \\
{[1.362]}\end{array}$ & $\begin{array}{c}-0.049 \\
{[0.079]}\end{array}$ & $\begin{array}{c}0.064 \\
{[0.058]}\end{array}$ & $\begin{array}{c}0.009 \\
{[0.034]}\end{array}$ \\
\hline \multicolumn{10}{|c|}{ parent characteristics (lagged) } \\
\hline Loan Loss & & $\begin{array}{c}\mathbf{- 0 . 6 2 4} * \\
{[0.341]}\end{array}$ & $\begin{array}{c}-0.950 \\
{[0.585]}\end{array}$ & & $\begin{array}{c}0.021 \\
{[0.271]}\end{array}$ & $\begin{array}{c}-0.269 \\
{[0.554]}\end{array}$ & & $\begin{array}{c}0.003 \\
{[0.017]}\end{array}$ & $\begin{array}{c}0.037 \\
{[0.034]}\end{array}$ \\
\hline$R O E$ & & $\begin{array}{c}-0.552 \\
{[0.333]}\end{array}$ & $\begin{array}{c}-1.640 \\
{[2.275]}\end{array}$ & & $\begin{array}{c}0.080 \\
{[0.364]}\end{array}$ & $\begin{array}{l}-1.132 \\
{[3.078]}\end{array}$ & & $\begin{array}{c}-0.014 \\
{[0.020]}\end{array}$ & $\begin{array}{c}-0.115 \\
{[0.113]}\end{array}$ \\
\hline Equity & & $\begin{array}{c}0.025 \\
{[2.174]}\end{array}$ & $\begin{array}{c}-0.158 \\
{[2.245]}\end{array}$ & & $\begin{array}{l}-1.391 \\
{[1.072]}\end{array}$ & $\begin{array}{c}-1.883 \\
{[1.216]}\end{array}$ & & $\begin{array}{c}-0.039 \\
{[0.054]}\end{array}$ & $\begin{array}{c}-0.070 \\
{[0.049]}\end{array}$ \\
\hline Liquidity & & $\begin{array}{c}0.784 \\
{[0.953]}\end{array}$ & $\begin{array}{c}2.274 \\
{[1.646]}\end{array}$ & & $\begin{array}{c}0.986 \\
{[1.216]}\end{array}$ & $\begin{array}{c}2.220 \\
{[1.398]}\end{array}$ & & $\begin{array}{c}-0.122 \\
{[0.111]}\end{array}$ & $\begin{array}{c}-0.135 \\
{[0.114]}\end{array}$ \\
\hline home country & & & & & & & & & \\
\hline GDP growth & & $\begin{array}{c}0.078 \\
{[5.262]}\end{array}$ & $\begin{array}{c}-0.589 \\
{[10.662]}\end{array}$ & & $\begin{array}{c}-1.362 \\
{[6.370]}\end{array}$ & $\begin{array}{c}-8.462 \\
{[17.051]}\end{array}$ & & $\begin{array}{c}-0.097 \\
{[0.145]}\end{array}$ & $\begin{array}{c}-0.005 \\
{[0.230]}\end{array}$ \\
\hline Crisis & & & $\begin{array}{c}0.710 \\
{[1.039]}\end{array}$ & & & $\begin{array}{c}0.673 \\
{[0.926]}\end{array}$ & & & $\begin{array}{c}-0.011 \\
{[0.021]}\end{array}$ \\
\hline interactions & & & & & & & & & \\
\hline Crisis $* P_{\text {LLoan Loss }}$ & & & $\begin{array}{c}-3.770 \\
{[2.957]}\end{array}$ & & & $\begin{array}{l}\mathbf{- 3 . 8 4 1 *} \\
{[2.011]}\end{array}$ & & & $\begin{array}{c}0.037 \\
{[0.030]}\end{array}$ \\
\hline Crisis*P_ROE & & & $\begin{array}{c}0.951 \\
{[2.665]}\end{array}$ & & & $\begin{array}{c}0.289 \\
{[3.014]}\end{array}$ & & & $\begin{array}{c}0.149 \\
{[0.117]}\end{array}$ \\
\hline Crisis*P_Equity & & & $\begin{array}{c}3.569 \\
{[7.231]}\end{array}$ & & & $\begin{array}{c}-0.958 \\
{[5.376]}\end{array}$ & & & $\begin{array}{c}-0.117 \\
{[0.110]}\end{array}$ \\
\hline Crisis $* P \_$Liquidity & & & $\begin{array}{c}-4.004 \\
{[2.740]}\end{array}$ & & & $\begin{array}{c}-6.77 \\
{[4.272]}\end{array}$ & & & $\begin{array}{c}-0.016 \\
{[0.053]}\end{array}$ \\
\hline Constant & $\begin{array}{c}-0.792 \\
{[0.786]}\end{array}$ & $\begin{array}{c}-0.835 \\
{[1.369]}\end{array}$ & $\begin{array}{c}-0.708 \\
{[1.291]}\end{array}$ & $\begin{array}{c}-0.712 \\
{[1.600]}\end{array}$ & $\begin{array}{c}0.428 \\
{[1.741]}\end{array}$ & $\begin{array}{c}-0.956 \\
{[1.914]}\end{array}$ & $\begin{array}{c}0.194 * * * \\
{[0.070]}\end{array}$ & $\begin{array}{c}0.115^{* *} \\
{[0.045]}\end{array}$ & $\begin{array}{l}0.090^{*} \\
{[0.047]}\end{array}$ \\
\hline Observations & 460 & 247 & 221 & 484 & 296 & 262 & 624 & 358 & 304 \\
\hline Number of banks & 80 & 52 & 46 & 89 & 62 & 56 & 104 & 72 & 63 \\
\hline R-squared & 0.038 & 0.077 & 0.107 & 0.007 & 0.019 & 0.052 & 0.273 & 0.078 & 0.077 \\
\hline
\end{tabular}

The table reports the fixed effects panel estimation results for developed countries. The dependent variables are $\Delta$ Time Deposits, yearly change in time deposits, $\Delta$ Bank Deposits, yearly change in bank deposits and Interest Rates, measured as total interest rate expenses to total interest bearing deposits. The third specification in each panel excludes the Asian parents. All variable definitions are presented in Table 1. Robust standard errors are in parentheses. *** significant at $1 \%$, ** significant at $5 \%, *$ significant at $10 \%$ 
Table 8 Market Discipline and Interbank Dependency

\begin{tabular}{|c|c|c|c|c|c|c|c|c|c|c|c|c|}
\hline & \multicolumn{6}{|c|}{ Interbank $<1$} & \multicolumn{6}{|c|}{ Interbank>1 } \\
\hline & \multicolumn{3}{|c|}{$\Delta$ Time Deposits } & \multicolumn{3}{|c|}{ Interest Rate } & \multicolumn{3}{|c|}{$\Delta$ Time Deposits } & \multicolumn{3}{|c|}{ Interest Rate } \\
\hline \multicolumn{13}{|c|}{ subsidiary characteristics } \\
\hline Loan Loss & $\begin{array}{c}-0.072 \\
{[0.095]}\end{array}$ & $\begin{array}{c}0.058 \\
{[0.240]}\end{array}$ & $\begin{array}{c}0.084 \\
{[0.296]}\end{array}$ & $\begin{array}{c}0.013 \\
{[0.013]}\end{array}$ & $\begin{array}{c}0.040 \\
{[0.030]}\end{array}$ & $\begin{array}{c}0.050 \\
{[0.031]}\end{array}$ & $\begin{array}{c}0.003 \\
{[0.075]}\end{array}$ & $\begin{array}{c}\mathbf{- 0 . 2 3 2} * * \\
{[0.108]}\end{array}$ & $\begin{array}{c}\mathbf{- 0 . 2 6 3} * * \\
{[0.113]}\end{array}$ & {$\left[\begin{array}{c}0.011 \\
{[0.007]}\end{array}\right.$} & $\begin{array}{c}0.018 \\
{[0.014]}\end{array}$ & $\begin{array}{c}0.020 \\
{[0.012]}\end{array}$ \\
\hline$R O E$ & $\begin{array}{l}-0.295 \\
{[0.198]}\end{array}$ & $\begin{array}{c}-0.346 \\
{[0.299]}\end{array}$ & $\begin{array}{c}-0.454 \\
{[0.349]}\end{array}$ & $\begin{array}{c}-0.004 \\
{[0.007]}\end{array}$ & $\begin{array}{c}-0.003 \\
{[0.010]}\end{array}$ & $\begin{array}{c}-0.001 \\
{[0.010]}\end{array}$ & $\begin{array}{c}-0.002 \\
{[0.050]}\end{array}$ & $\begin{array}{c}-0.174 \\
{[0.260]}\end{array}$ & $\begin{array}{c}-0.248 \\
{[0.354]}\end{array}$ & $\begin{array}{c}0.012 \\
{[0.016]}\end{array}$ & $\begin{array}{c}-0.040 \\
{[0.040]}\end{array}$ & $\begin{array}{c}-0.07 \\
{[0.058]}\end{array}$ \\
\hline Equity & $\begin{array}{c}\mathbf{- 4 . 5 0 9} * * * \\
{[1.161]}\end{array}$ & $\begin{array}{c}-\mathbf{7 . 5 8 2} * * \\
{[3.748]}\end{array}$ & $\begin{array}{l}-7.096 * \\
{[4.033]}\end{array}$ & $\begin{array}{c}0.016 \\
{[0.097]}\end{array}$ & $\begin{array}{c}-0.020 \\
{[0.291]}\end{array}$ & $\begin{array}{c}0.004 \\
{[0.293]}\end{array}$ & $\begin{array}{c}1.748 \\
{[1.218]}\end{array}$ & $\begin{array}{l}\text { 3.539* } \\
{[2.037]}\end{array}$ & $\begin{array}{c}\mathbf{4 . 3 5 6} * * \\
{[2.124]}\end{array}$ & {$\left[\begin{array}{c}0.154 \\
{[0.118]}\end{array}\right.$} & $\begin{array}{c}0.040 \\
{[0.112]}\end{array}$ & $\begin{array}{c}0.081 \\
{[0.119]}\end{array}$ \\
\hline Liquidity & $\begin{array}{c}0.934 \\
{[0.592]}\end{array}$ & $\begin{array}{c}1.302 \\
{[0.890]}\end{array}$ & $\begin{array}{c}1.137 \\
{[0.820]}\end{array}$ & $\begin{array}{c}0.013 \\
{[0.020]}\end{array}$ & $\begin{array}{c}0.013 \\
{[0.024]}\end{array}$ & $\begin{array}{c}0.016 \\
{[0.028]}\end{array}$ & $\begin{array}{c}0.297 \\
{[0.527]}\end{array}$ & $\begin{array}{c}0.946 \\
{[0.867]}\end{array}$ & $\begin{array}{c}0.823 \\
{[1.002]}\end{array}$ & {$\left[\begin{array}{l}-0.009 \\
{[0.054]}\end{array}\right.$} & $\begin{array}{c}-0.003 \\
{[0.060]}\end{array}$ & $\begin{array}{c}-0.010 \\
{[0.074]}\end{array}$ \\
\hline Size & $\begin{array}{c}-0.028 \\
{[0.207]}\end{array}$ & $\begin{array}{c}0.036 \\
{[0.265]}\end{array}$ & $\begin{array}{c}0.193 \\
{[0.323]}\end{array}$ & $\begin{array}{c}-0.013 \\
{[0.013]}\end{array}$ & $\begin{array}{c}-0.021 \\
{[0.025]}\end{array}$ & $\begin{array}{c}-0.013 \\
{[0.026]}\end{array}$ & $\begin{array}{c}0.027 \\
{[0.132]}\end{array}$ & $\begin{array}{c}0.240 \\
{[0.243]}\end{array}$ & $\begin{array}{c}0.463 \\
{[0.304]}\end{array}$ & {$\left[\begin{array}{c}0.019 \\
{[0.015]}\end{array}\right.$} & $\begin{array}{c}0.009 \\
{[0.014]}\end{array}$ & $\begin{array}{c}0.008 \\
{[0.018]}\end{array}$ \\
\hline \multicolumn{13}{|l|}{ host country } \\
\hline GDP growth & $\begin{array}{c}-0.614 \\
{[1.672]}\end{array}$ & $\begin{array}{c}-2.157 \\
{[2.346]}\end{array}$ & $\begin{array}{c}-2.567 \\
{[2.494]}\end{array}$ & $\begin{array}{c}\mathbf{- 0 . 3 6 4} * * \\
{[0.148]}\end{array}$ & $\begin{array}{c}\mathbf{- 0 . 4 6 0} * * * \\
{[0.162]}\end{array}$ & $\begin{array}{c}\mathbf{- 0 . 4 2 6} * * \\
{[0.178]}\end{array}$ & $\begin{array}{c}\mathbf{4 . 4 5 4} * * * \\
{[1.515]}\end{array}$ & $\begin{array}{c}2.264 \\
{[2.468]}\end{array}$ & $\begin{array}{c}2.353 \\
{[3.463]}\end{array}$ & $\begin{array}{l}-0.926 * \\
{[0.498]}\end{array}$ & $\begin{array}{c}-0.125 \\
{[0.343]}\end{array}$ & $\begin{array}{c}-0.152 \\
{[0.411]}\end{array}$ \\
\hline Exchange rate & $\begin{array}{c}0.618 \\
{[0.486]}\end{array}$ & $\begin{array}{l}-0.189 \\
{[0.670]}\end{array}$ & $\begin{array}{c}0.099 \\
{[0.551]}\end{array}$ & $\begin{array}{c}-0.026 \\
{[0.048]}\end{array}$ & $\begin{array}{c}0.019 \\
{[0.050]}\end{array}$ & $\begin{array}{c}0.031 \\
{[0.057]}\end{array}$ & $\begin{array}{c}\mathbf{0 . 0 8 4} * * * \\
{[0.018]}\end{array}$ & $\begin{array}{c}0.630 \\
{[0.516]}\end{array}$ & $\begin{array}{c}0.579 \\
{[0.607]}\end{array}$ & $\begin{array}{c}0.001 \\
{[0.003]}\end{array}$ & $\begin{array}{c}-0.075 \\
{[0.059]}\end{array}$ & $\begin{array}{c}-0.004 \\
{[0.067]}\end{array}$ \\
\hline Concentration & $\begin{array}{c}0.674 \\
{[1.343]}\end{array}$ & $\begin{array}{c}-1.701 \\
{[2.557]}\end{array}$ & $\begin{array}{l}-1.049 \\
{[2.430]}\end{array}$ & $\begin{array}{c}-0.001 \\
{[0.066]}\end{array}$ & $\begin{array}{c}-0.056 \\
{[0.097]}\end{array}$ & $\begin{array}{c}-0.042 \\
{[0.104]}\end{array}$ & $\begin{array}{c}-0.721 \\
{[1.363]}\end{array}$ & $\begin{array}{c}2.450 \\
{[1.632]}\end{array}$ & $\begin{array}{l}5.232 * * \\
{[2.272]}\end{array}$ & $\begin{array}{c}0.175 \\
{[0.192]}\end{array}$ & $\begin{array}{c}-0.145 \\
{[0.127]}\end{array}$ & $\begin{array}{c}-0.140 \\
{[0.169]}\end{array}$ \\
\hline \multicolumn{13}{|c|}{ parent characteristics } \\
\hline Loan Loss & & $\begin{array}{c}\mathbf{- 2 . 3 2 1} * * \\
{[1.072]}\end{array}$ & $\begin{array}{c}\mathbf{- 2 . 8 9 7} * * * * \\
{[1.035]}\end{array}$ & & $\begin{array}{c}-0.014 \\
{[0.037]}\end{array}$ & $\begin{array}{c}0.012 \\
{[0.047]}\end{array}$ & & $\begin{array}{c}0.231 \\
{[0.173]}\end{array}$ & $\begin{array}{c}-0.033 \\
{[0.440]}\end{array}$ & & $\begin{array}{c}\mathbf{0 . 0 6 5} * * \\
{[0.028]}\end{array}$ & $\begin{array}{c}0.081 \\
{[0.060]}\end{array}$ \\
\hline$R O E$ & & $\begin{array}{c}0.308 \\
{[1.272]}\end{array}$ & $\begin{array}{c}-0.057 \\
{[2.150]}\end{array}$ & & $\begin{array}{c}-0.116 \\
{[0.103]}\end{array}$ & $\begin{array}{c}-0.116 \\
{[0.126]}\end{array}$ & & $\begin{array}{c}0.388 \\
{[0.407]}\end{array}$ & $\begin{array}{l}-3.206 \\
{[2.873]}\end{array}$ & & $\begin{array}{c}0.106^{*} \\
{[0.058]}\end{array}$ & $\begin{array}{c}\mathbf{0 . 6 3 8} * * \\
{[0.314]}\end{array}$ \\
\hline Equity & & $\begin{array}{c}8.491 \\
{[8.952]}\end{array}$ & $\begin{array}{c}9.877 \\
{[10.407]}\end{array}$ & & $\begin{array}{c}-0.587 \\
{[0.990]}\end{array}$ & $\begin{array}{c}-0.224 \\
{[0.779]}\end{array}$ & & $\begin{array}{c}-3.881 \\
{[2.457]}\end{array}$ & $\begin{array}{c}\mathbf{- 6 . 0 9 9} * * * \\
{[2.107]}\end{array}$ & & $\begin{array}{c}0.103 \\
{[0.233]}\end{array}$ & $\begin{array}{c}0.073 \\
{[0.250]}\end{array}$ \\
\hline Liquidity & & $\begin{array}{c}1.044 \\
{[4.854]}\end{array}$ & $\begin{array}{c}1.195 \\
{[6.957]}\end{array}$ & & $\begin{array}{c}-0.164 \\
{[0.189]}\end{array}$ & $\begin{array}{c}-0.159 \\
{[0.183]}\end{array}$ & & $\begin{array}{c}-0.923 \\
{[2.085]}\end{array}$ & $\begin{array}{l}-0.455 \\
{[2.244]}\end{array}$ & & $\begin{array}{c}0.042 \\
{[0.191]}\end{array}$ & $\begin{array}{c}-0.094 \\
{[0.208]}\end{array}$ \\
\hline home & & & & & & & & & & & & \\
\hline GDP growth & & $\begin{array}{c}\mathbf{1 5 . 0 2 5} * \\
{[8.255]}\end{array}$ & $\begin{array}{c}14.852 \\
{[9.230]}\end{array}$ & & $\begin{array}{c}-0.948 \\
{[0.599]}\end{array}$ & $\begin{array}{c}-1.063 \\
{[0.664]}\end{array}$ & & $\begin{array}{c}\text { 13.752*** } \\
{[6.634]}\end{array}$ & $\begin{array}{c}18.771 \\
{[11.333]}\end{array}$ & & $\begin{array}{c}0.613 \\
{[0.913]}\end{array}$ & $\begin{array}{c}0.285 \\
{[1.060]}\end{array}$ \\
\hline Crisis & & & $\begin{array}{c}-0.596 \\
{[1.276]}\end{array}$ & & & $\begin{array}{c}0.045 \\
{[0.080]}\end{array}$ & & & $\begin{array}{c}\mathbf{- 1 . 7 8 4} * * * * \\
{[0.604]}\end{array}$ & & & $\begin{array}{c}-0.015 \\
{[0.075]}\end{array}$ \\
\hline interactions & & & & & & & & & & & & \\
\hline Crisis $* P \_$Loan Loss & & & $\begin{array}{c}\mathbf{4 . 8 1 8} * * \\
{[2.310]}\end{array}$ & & & $\begin{array}{c}0.016 \\
{[0.152]}\end{array}$ & & & $\begin{array}{c}1.115 \\
{[0.827]}\end{array}$ & & & $\begin{array}{c}0.123 \\
{[0.110]}\end{array}$ \\
\hline Crisis $* P \_R O E$ & & & $\begin{array}{c}1.489 \\
{[2.421]}\end{array}$ & & & $\begin{array}{c}-0.002 \\
{[0.168]}\end{array}$ & & & $\begin{array}{c}5.323 \\
{[3.508]}\end{array}$ & & & $\begin{array}{c}-0.343 \\
{[0.316]}\end{array}$ \\
\hline Crisis $* P_{\text {EEquity }}$ & & & $\begin{array}{c}-2.719 \\
{[8.754]}\end{array}$ & & & $\begin{array}{c}-0.716 \\
{[0.758]}\end{array}$ & & & $\begin{array}{c}12.418 * * * * \\
{[4.648]}\end{array}$ & & & $\begin{array}{c}0.111 \\
{[0.628]}\end{array}$ \\
\hline Crisis $* P \_$Liquidity & & & $\begin{array}{c}1.170 \\
{[5.725]}\end{array}$ & & & $\begin{array}{c}-0.150 \\
{[0.259]}\end{array}$ & & & $\begin{array}{c}-0.206 \\
{[1.737]}\end{array}$ & & & $\begin{array}{c}0.190 \\
{[0.181]}\end{array}$ \\
\hline Constant & $\begin{array}{c}0.201 \\
{[1.427]}\end{array}$ & $\begin{array}{c}0.585 \\
{[2.844]}\end{array}$ & $\begin{array}{c}-0.957 \\
{[3.229]}\end{array}$ & $\begin{array}{l}0.216 * * \\
{[0.084]}\end{array}$ & $\begin{array}{l}0.397 * \\
{[0.228]}\end{array}$ & $\begin{array}{c}0.307 \\
{[0.205]}\end{array}$ & $\begin{array}{c}-0.314 \\
{[1.293]}\end{array}$ & $\begin{array}{c}-4.077 * * \\
{[1.663]}\end{array}$ & $\begin{array}{c}-6.694 * * * \\
{[2.055]}\end{array}$ & $\begin{array}{c}-0.076 \\
{[0.181]}\end{array}$ & $\begin{array}{c}0.149 \\
{[0.118]}\end{array}$ & $\begin{array}{c}0.097 \\
{[0.146]}\end{array}$ \\
\hline Observations & 293 & 177 & 173 & 425 & 283 & 279 & 505 & 247 & 214 & 622 & 330 & 297 \\
\hline Number of banks & 98 & 62 & 59 & 123 & 81 & 78 & 124 & 71 & 65 & 146 & 86 & 80 \\
\hline R-squared & 0.076 & 0.164 & 0.198 & 0.029 & 0.063 & 0.073 & 0.042 & 0.112 & 0.166 & 0.044 & 0.03 & 0.058 \\
\hline
\end{tabular}

The table reports the fixed effects panel estimation results for developing countries. The dependent variables are $\Delta$ Time Deposits, yearly change in time deposits, $\Delta$ Bank Deposits, yearly change in bank deposits and Interest Rates, measured as total interest rate expenses to total interest bearing deposits. The first (second) six specifications report the results for the sample with an interbank ratio below (above) its median. The third specification in each panel excludes the Asian parents. All variable definitions are presented in Table 1 . Robust standard errors are in parentheses. $* * *$ significant at $1 \%$, ** significant at $5 \%$, significant at $10 \%$ 


\section{Appendix \\ Table A1}

\begin{tabular}{|c|c|c|}
\hline Name of parent bank & Country of origin & $\begin{array}{c}\text { Number of } \\
\text { subsidiaries }\end{array}$ \\
\hline Allied Irish Banks plc & IRELAND & 1 \\
\hline Alpha Bank AE & GREECE & 5 \\
\hline Australia and New Zealand Banking Group & AUSTRALIA & 5 \\
\hline BNP Paribas & FRANCE & 19 \\
\hline Banca Monte dei Paschi di Siena SpA & ITALY & 3 \\
\hline Banco Bilbao Vizcaya Argentaria SA & SPAIN & 6 \\
\hline Banco Santander SA & SPAIN & 15 \\
\hline Bank of America, National As sociation & USA & 9 \\
\hline Barclays plc & UNITED KINGDOM & 15 \\
\hline Bayerische Landesbank & GERMANY & 10 \\
\hline Citibank NA & USA & 51 \\
\hline Commerzbak AG & GERMANY & 6 \\
\hline Commonwealth Bank of Australia & AUSTRALIA & 1 \\
\hline Credit Suisse Group & SWITZERLAND & 9 \\
\hline CrÈdit Agricole S.A. & FRANCE & 15 \\
\hline DBS Group Holdings Ltd & SINGAPORE & 4 \\
\hline Danske Bank A/S & DENMARK & 4 \\
\hline Deutsche Bank AG & GERMANY & 20 \\
\hline Deutsche Zentral-Genossenschaftsbank AG & GERMANY & 2 \\
\hline Dexia Bank-Dexia Bank Belgium & BELGIUM & 9 \\
\hline DnB Nor ASA & NORWAY & 4 \\
\hline Dresdner Bank AG & GERMANY & 9 \\
\hline EFG Eurobank Ergasias SA & GREECE & 5 \\
\hline Erste Group Bank AG & AUSTRIA & 8 \\
\hline Fortis & BELGIUM & 5 \\
\hline HSBC Holdings Plc & UNITED KINGDOM & 29 \\
\hline INGBank NV & NETHERLANDS & 9 \\
\hline Intesa Sanpaolo & ITALY & 8 \\
\hline JP Morgan Chase Bank, NA & USA & 16 \\
\hline KBC Bank NV & BELGIUM & 7 \\
\hline \multicolumn{3}{|l|}{ Kabushiki Kaisha Mitsubishi UFJ Financial Group- } \\
\hline Mitsubishi UFJ Financial Group Inc & JAPAN & 16 \\
\hline Kookmin Bank & KOREA REP. OF & 3 \\
\hline Landesbank Baden-Wuerttemberg & GERMANY & 1 \\
\hline Millennium bcp-Banco Comercial PortuguÍs, SA & PORTUGAL & 6 \\
\hline Mizuho Financial Group & JAPAN & 8 \\
\hline Nordea Bank AB (publ) & SWEDEN & 4 \\
\hline Rabobank Nederland & NETHERLANDS & 10 \\
\hline Raiffeisen Zentralbank Oesterreich AG - RZB & AUSTRIA & 14 \\
\hline Royal Bank of Scotland Group Plc (The) & UNITED KINGDOM & 10 \\
\hline Shinhan Bank & KOREA REP. OF & 5 \\
\hline Skandinaviska Enskilda Banken AB & SWEDEN & 6 \\
\hline SociÈtÈ GÈnÈrale & FRANCE & 11 \\
\hline Standard Chartered Plc & UNITED KINGDOM & 26 \\
\hline Sumitomo Mitsui Financial Group, Inc & JAPAN & 7 \\
\hline Svenska Handelsbanken & SWEDEN & 2 \\
\hline Swedbank AB & SWEDEN & 5 \\
\hline UBS AG & SWITZERLAND & 13 \\
\hline UniCredit SpA & ITALY & 15 \\
\hline WestLB AG & GERMANY & 8 \\
\hline Westpac Banking Corporation & AUSTRALIA & 5 \\
\hline Woori Bank & KOREA REP. OF & 3 \\
\hline
\end{tabular}


Table A2

\begin{tabular}{|c|c|c|c|}
\hline Country & $\begin{array}{c}\text { Number of } \\
\text { subsidiaries }\end{array}$ & Country & $\begin{array}{c}\text { Number of } \\
\text { subsidiaries }\end{array}$ \\
\hline Albania & 2 & Lebanon & 2 \\
\hline Angola & 1 & Lithuania & 5 \\
\hline Argentina & 9 & Macedonia & 1 \\
\hline Armenia & 2 & Madagascar & 1 \\
\hline Australia & 5 & Malaysia & 7 \\
\hline Austria & 5 & Mauritania & 1 \\
\hline Belgium & 12 & Mauritius & 2 \\
\hline Bolivia & 1 & Mexico & 11 \\
\hline Bosnia and Herzegovina & 5 & Montenegro & 1 \\
\hline Botswana & 2 & Morocco & 2 \\
\hline Brazil & 16 & Mozambique & 1 \\
\hline Bulgaria & 8 & Nepal & 1 \\
\hline Cambodia & 1 & Netherlands & 9 \\
\hline Cameroon & 2 & New Zealand & 4 \\
\hline Canada & 13 & Nicaragua & 1 \\
\hline Chile & 11 & Nigeria & 1 \\
\hline China & 9 & Norway & 3 \\
\hline Colombia & 5 & Pakistan & 2 \\
\hline Congo, Dem. Rep. & 1 & Panama & 10 \\
\hline Costa Rica & 2 & Papua New Guinea & 2 \\
\hline Croatia & 6 & Paraguay & 4 \\
\hline Czech Republic & 8 & Peru & 4 \\
\hline Denmark & 3 & Philippines & 2 \\
\hline Dominican Republic & 1 & Poland & 22 \\
\hline Ecuador & 1 & Portugal & 5 \\
\hline Egypt, Arab Rep. & 5 & Romania & 7 \\
\hline El Salvador & 2 & Russian Federation & 26 \\
\hline Equatorial Guinea & 1 & Serbia & 10 \\
\hline Estonia & 2 & Sierra Leone & 1 \\
\hline Finland & 1 & Singapore & 3 \\
\hline France & 13 & Slovak Republic & 6 \\
\hline Gabon & 1 & Slovenia & 4 \\
\hline Gambia, The & 1 & Spain & 12 \\
\hline Germany & 15 & Taiwan & 2 \\
\hline Ghana & 2 & Tanzania & 3 \\
\hline Greece & 1 & Thailand & 2 \\
\hline Guatemala & 1 & Tonga & 1 \\
\hline Honduras & 2 & Trinidad and Tobago & 1 \\
\hline Hong Kong & 6 & Tunisia & 1 \\
\hline Hungary & 12 & Turkey & 6 \\
\hline India & 6 & Uganda & 3 \\
\hline Indonesia & 10 & Ukraine & 8 \\
\hline Ireland & 13 & United Kingdom & 14 \\
\hline Italy & 6 & Uruguay & 5 \\
\hline Ivory Coast & 2 & Usa & 14 \\
\hline Japan & 1 & Venezuela & 2 \\
\hline Kazakhstan & 2 & Vietnam & 1 \\
\hline Kenya & 3 & Zambia & 3 \\
\hline Korea, Rep. & 2 & Zimbabwe & 2 \\
\hline Latvia & 5 & & \\
\hline
\end{tabular}

